Laboratoire de Recherche en Gestion $\&$ Economie
Is Corruption an Efficient Grease ?

Pierre-Guillaume Méon , Laurent Weill

Février 2008
Faculté des sciences économiques et de gestion

PEGE

61, avenue de la Forêt Noire 67085 STRASBOURG Cedex

Tél. : (33) 0390242152

Fax : (33) 0390242064 www-ulp.u-strasbg.fr/large

Institut d'Etudes Politiques 47, avenue de la Forêt Noire 67082 STRASBOURG Cedex 


\title{
Is corruption an efficient grease?
}

\author{
Pierre-Guillaume Méon $^{1 *}$, Laurent Weill ${ }^{2}$
}

${ }^{1}$ Université Libre de Bruxelles (ULB), DULBEA, CP-140, avenue F.D. Roosevelt 50, 1050 Bruxelles, Belgium. (phone: +32 265066 48, fax: +32 265038 25, e-mail: pgmeon@ulb.ac.be)

2 Université Robert Schuman, Institut d'Etudes Politiques, 47 avenue de la Forêt Noire, 67082 Strasbourg Cedex, France. (phone: +33 3884177 21, fax: +33 3884177 78, e-mail: laurent.weill@iep.ustrasbg.fr)

\begin{abstract}
This paper tests whether corruption can be viewed as an efficient grease in the wheels of an otherwise deficient institutional framework. It does so by analyzing the interaction between aggregate efficiency, corruption, and other dimensions of governance for a panel of 54 countries both developed and developing. Using three measures of corruption and five measures of other aspects of governance, we repeatedly observe that corruption is always detrimental in countries where institutions are effective, but that it may be positively associated with efficiency in countries where institutions are ineffective. We thus find evidence of the grease the wheels hypothesis.
\end{abstract}

Keywords: governance, corruption, income, aggregate productivity, efficiency.

JEL Classification: C33, K4, O43, 047.

\footnotetext{
${ }^{*}$ Corresponding author.
} 


\title{
Is corruption an efficient grease?
}

\begin{abstract}
This paper tests whether corruption can be viewed as an efficient grease in the wheels of an otherwise deficient institutional framework. It does so by analyzing the interaction between aggregate efficiency, corruption, and other dimensions of governance for a panel of 54 countries both developed and developing. Using three measures of corruption and five measures of other aspects of governance, we repeatedly observe that corruption is always detrimental in countries where institutions are effective, but that it may be positively associated with efficiency in countries where institutions are ineffective. We thus find evidence of the grease the wheels hypothesis.
\end{abstract}

Keywords: governance, corruption, income, aggregate productivity, efficiency.

JEL Classification: C33, K4, O43, 047.

\section{Introduction}

Very few people would dare say that corruption is efficient. ${ }^{1}$ Nevertheless some scholars, many of whom are economists, may. Leys (1965) even went so far as to wonder what "the problem about corruption" was. This provocative claim is backed by various theoretical justifications, as Aidt (2003)'s survey shows, but the most common argument in favor of the beneficial effects of corruption rests on what is commonly referred to as the "grease the wheels" hypothesis. According to that hypothesis, put forward by Leff (1964), Leys (1965), or Huntington (1968), corruption may be beneficial in a second best world by alleviating the distortions caused by ill-functioning institutions. The grease the wheels argument postulates that an inefficient bureaucracy constitutes a major impediment to economic activity that some "speed" or "grease" money may help circumvent. Lui (1985) offers a formal illustration of this argument and showed that corruption may be an efficient way of reducing the time cost of queues. In a nutshell, the grease the wheels hypothesis states that, in a second best world, graft may act as a trouble-saving device, thereby raising efficiency.

\footnotetext{
${ }^{1}$ Corruption is understood here as the misuse of public office for private benefit, as is now common in the literature.
} 
Policy circles however do not share the idea that corruption may sometimes be efficient. On the contrary, international organizations like the IMF or the OECD, view corruption as a major hindrance to economic development. As a result, the fight against corruption has raised considerable attention. This has resulted in international initiatives such as the UN Convention against Corruption, adopted in 2003, or the OECD's "Convention on combating bribery of foreign public officials in international business transactions", which came into force in April 1999.

This point of view was recently backed by a strand of empirical literature aimed at quantifying the consequences of corruption. This literature was pioneered by Mauro (1995), who observed a significant negative relationship between corruption and investment that extended to growth. Mauro (1995)'s results were later confirmed by Mo (2001) for example, and extended to other macroeconomic variables like foreign direct investment by Wei (2000), or productivity by Lambsdorff (2003).

Strictly speaking though, this evidence does not allow to reject the grease the wheels hypothesis but may in fact be consistent with it. Indeed, the hypothesis simply implies that corruption is beneficial in countries where other aspects of governance are defective, but remains detrimental elsewhere. Therefore, the mere observation that corruption is on average associated with more disappointing economic outcomes does not prevent the correlation from being positive in those countries where governance is mediocre. The average result may thus be driven by the negative correlation between corruption and economic performance in the subset of countries whose institutional framework is effective, whereas the correlation may indeed be positive elsewhere.

To our knowledge, attempts to specifically test the grease the wheels hypothesis remain scarce. Mauro (1995) rejected it on the grounds that he could observe no significant difference in the relationship between corruption and the investment ratio between high redtape and low red-tape countries. Ades and di Tella (1997) also rejected the hypothesis. Kaufmann and Wei (1999) tackled the issue from a different angle by using firm-level data. They observed that multinationals that pay more bribes also tend to spend more time negotiating with foreign countries' officials, which is hard to reconcile with the grease the wheels hypothesis. Méon and Sekkat (2005) studied the hypothesis from a macroeconomic perspective. They observed that corruption was detrimental to investment and growth everywhere, and especially so in countries with an otherwise defective institutional framework. This goes against what the grease the wheels hypothesis predicts but may reveal a "sand the wheels" effect of corruption. 
However, those contributions do not study the main determinant of cross-country differences in economic performance, i.e. productivity, choosing to focus instead on factor accumulation and endowments. Yet, evidence that cross-country differences in economic performance are the result of differences in productivity is overwhelming, as Caselli (2005)'s recent survey points out. Consequently, in order to test the economic significance of corruption and of the grease the wheels hypothesis, one must focus on productivity. In other words, one must wonder whether corruption helps countries with faulty institutions to take a better advantage of their factor endowments. This is precisely the aim of the present paper.

To do so, this study applies efficiency frontiers to aggregate production functions, following Moroney and Lovell (1997). That method provides a synthetic measure of the gap between countries' observed and optimal productions. The interrelationship between corruption, efficiency, and the quality of the institutional framework can then be investigated to test the grease the wheels hypothesis. This is done by assessing the interaction between corruption and a wide range of indicators of the quality of governance, for a panel of countries. The results appear to be inconsistent with the sand the wheels hypothesis. Instead, they hint at the reverse hypothesis, the grease the wheels hypothesis, which posits that corruption is even more harmful to efficiency when governance is poor.

To reach these conclusions, the remainder of this paper is organized as follows. The next section briefly describes the grease the wheels and the sand the wheels hypotheses. Section 3 outlines our method. Our data set is presented in section 4 . We present our empirical results in section 5. Concluding comments may be found in section 6 .

\section{Two testable hypotheses}

The grease the wheels hypothesis finds its roots in a literature aimed at qualifying the conclusions of what was dubbed the "moralistic view" of corruption. ${ }^{2}$ Some scholars have stressed that corruption may have its own merits in fostering development, and should therefore not be judged solely on moral grounds. Their line of reasoning has often rested on a few similar considerations emphasizing the accommodative properties of graft in the presence of other imperfections in the rest of the political system. However one may also think of

\footnotetext{
${ }^{2}$ The expression "moralistic approach" can for instance be found in Leys (1965) or Nye (1967). Those who opposed that view were later deemed "functionalists" or "revisionists" by their own adversaries. On a general plane, they seemed to be motivated by a concern that the moral implications of corruption may bias the understanding of its economic consequences and by some concern that the western definition of graft may make it ill-adapted to the context of developing countries.
} 
mechanisms that may make corruption even more costly when institutions are deficient. These mechanisms are at the core of the sand the wheels hypothesis.

The basis of both hypotheses lies in the distinction between corruption and other institutional deficiencies. Leff (1964) for instance made a distinction between corruption as such and the inefficiency of bureaucracy, namely its incapacity to attain goals it is given. A survey of the two hypotheses is provided by Méon and Sekkat (2005). To save on space, the present section only draws on that survey to describe how the impact of corruption on efficiency may depend on the quality of the rest of the institutional framework. Our aim is to identify a strategy to test the grease the wheels and the sand the wheels hypotheses against each other.

\subsection{The grease the wheels hypothesis}

Unsurprisingly, the inefficiency of bureaucracy has often been considered the most prominent inefficiency that corruption can grease. ${ }^{3}$ The first bureaucratic inefficiency that can be compensated by corruption is slowness. Leys (1965) therefore stressed that bribes could give bureaucrats an incentive to speed up the establishment of new firms, in an otherwise sluggish administration. The same argument was later adopted by Lui (1985) who showed in a formal model that corruption could efficiently reduce the time spent in queues. It can also be argued that corruption can amend a bureaucracy by improving the quality of its civil servants. As Leys (1965) or Bailey (1966) claim, when government service wages are low, the possibility of perks may attract able civil servants who would otherwise have opted for another line of business.

Some, such as Leff (1964) or Bailey (1966), also argue that graft may simply be a hedge against bad public policies. In these authors' view, this is particularly true if the bureaucrat is biased against entrepreneurship, for ideological reasons or due to a prejudice against certain minority groups. ${ }^{4}$ By simply impeding inefficient regulations, corruption may then limit their adverse effects. The causality may in fact be subtler. Ehrlich and Lui (1999) thus argue that autocratic regimes, which are able to steer the administration in a centralized way, implement policies that are closer, if not equivalent, to first best policies. The reason is that they wish to maximize their rents but internalize the deadweight loss associated with

\footnotetext{
${ }^{3}$ As Huntington (1968, p.386) put it: "In terms of economic growth, the only thing worse than a society with a rigid, overcentralized, dishonest bureaucracy is one with a rigid, overcentralized, honest bureaucracy".

${ }^{4}$ Nye (1967) by example reports that corruption was instrumental in making central planning more effective in the Soviet Union. He also argues that it helped increase the influence of Asian minority entrepreneurs in East Africa beyond what political conditions would have allowed.
} 
corruption. These regimes have therefore incentives to avoid impairing the productivity of the private sector. This incentive does not exist in more decentralized regimes where no bureaucrat perceives the detrimental effect of bribes on productivity. We may conclude that corruption provides an incentive to implement better policies in autocratic regimes but not in democratic regimes. All things being equal, it is therefore beneficial in countries that are less democratic.

Moreover, it has also been argued that graft may in some circumstances improve the quality of investments. This is in particular the case, as Leff(1964) stresses, when government spending is inefficient. If corruption is a means of tax evasion, it can reduce the revenue of public taxes and, provided bribers have efficient investment opportunities, improve the overall efficiency of investment. More generally, one may contend that corruption is an efficient way of selecting investment projects, when such investments depend on gaining a license. Bailey (1966) for instance claims that this may be true if the ability to offer a bribe is correlated with talent. More specifically, one may argue that awarding a license through corrupt methods is very similar to a competitive auction. This intuition was offered by Leff (1964) who argues that favors tend to be allocated to the more generous bribers, who can only be the most efficient. Beck and Maher (1986) and Lien (1986) subsequently showed formally that corruption replicates the outcome of a competitive auction aimed at attributing a government procurement contract, because the ranking of bribes replicates the ranking of firms by efficiency.

All the above-mentioned arguments share the presumption that corruption may positively contribute to the productivity of the factors of production with which a country is endowed, because it compensates for the consequences of a defective institutional framework, resulting in an inefficient administration, a low rule of law, or political violence. One may nevertheless remark that graft also has its drawbacks. Indeed, although bribery may have its benefits, it may also impose additional costs in a weak institutional environment. The existence of such costs provides a rationale for the sand the wheels hypothesis.

\subsection{The sand the wheels hypothesis}

The specificity of the sand the wheels hypothesis is that it emphasizes that some of the costs of corruption may precisely appear or be magnified in a weak institutional context.

For instance, the claim that corruption may speed up an otherwise sluggish bureaucracy can be overturned. Myrdal (1968) argues that corrupt civil servants may cause 
delays that would otherwise not appear, just to get the opportunity to extract a bribe. Kurer (1993) argues along similar lines that corrupt officials have an incentive to create other distortions in the economy to preserve their illegal source of income. These arguments are perfectly compatible with the experience of individual bribers who can indeed improve their own situation thanks to a perk. They stress however that nothing may be gained from corruption at the aggregate level. ${ }^{5}$

Moreover, there are reasons to believe that corruption may not be the best way to award a license to the most efficient producer. Thus, even if the analogy between corruption and a competitive auction holds true, the winner is not necessarily the most efficient. In auctions where the profitability of a license is uncertain, the winner may simply be the more optimistic, according to the "winner's curse". Secondly, as Rose-Ackerman (1997) argues, the highest briber may simply be the one most willing to compromise on the quality of the goods he will produce if he gets a license. Under those circumstances, corruption will simply reduce rather than improve efficiency.

The argument that states that corruption may raise the quality of investment is also questionable. There is evidence that this may not be true for public investment. Thus, Mauro (1998) observes that corruption results in a diversion of public spending towards less efficient allocations. Overall, corruption therefore results in a greater amount of public investments in unproductive sectors, which is unlikely to improve efficiency and result in faster growth.

One can also doubt that corruption may serve as a hedge against risk in a politically uncertain environment. This can only be true if corruption does not imply additional risktaking. However, corruption is not a simple transaction. As it is illegal, the commitment to comply with the terms of the agreement may indeed be very weak, which may lead to opportunism, especially on the bribee's part. Furthermore, increased uncertainty due to corruption may go beyond corrupt deals themselves. Thus, larger corruption was found to be associated with a larger shadow economy, for instance by Dreher and Schneider (2006a, b). Since transactions in the shadow economy are by definition unregulated they are therefore subject to greater uncertainty than official transactions.

Consequently, as Bardhan (1997) points out, the inherent uncertainty of corrupt agreements may simply make the efficiency-enhancing mechanisms described in the previous

\footnotetext{
${ }^{5}$ Those effects can be exacerbated when the administration is made of a succession of decision centers or civil servants. Shleifer and Vishny (1993) thus build a formal model where the cost of corruption is greater when the administration is made of many independent agencies than when it is centrally managed.
} 
section ineffective. This may provide an incentive to invest in general, as opposed to specific, capital, which can easily be reallocated but is also less productive, as Henisz (2000) argues. As a result, corruption may worsen the impact of political violence or a weak rule of law on the quality of investment instead of reducing it.

To conclude, both the grease the wheels and the sand the wheels hypotheses may seem reasonable on an abstract plane. However, they both remain very theoretical. Even so, they both produce testable hypotheses that are summarized in table 1 below:

Table 1

Impact of corruption on efficiency

\begin{tabular}{|l|c|c|}
\cline { 2 - 3 } \multicolumn{1}{c|}{} & Grease the wheels & Sand the wheels \\
\hline Effective institutions & detrimental & detrimental \\
\hline Ineffective institutions & positive & detrimental \\
\hline
\end{tabular}

According to table 1, both hypotheses predict that an increase in corruption will reduce efficiency in an otherwise efficient institutional context. They differ however in the expected impact of corruption in a deficient institutional context. Namely, the grease the wheels hypothesis predicts that corruption may help raise efficiency. By contrast, the sand the wheels hypothesis predicts that an increase in corruption will reduce efficiency, even in a deficient institutional context. In the next section, we describe how we put these two competing hypotheses to an empirical trial.

\section{Methodology}

In this section, we explain how we measure aggregate efficiency, and then present its determinants that are taken into account.

\subsection{Measuring efficiency}

Our aim is to measure aggregate efficiency in order to assess its link with corruption. With this end in mind, we apply frontier efficiency techniques. Namely, we assess technical efficiency, which measures how close a country's production is to what a country's optimal production would be for using the same bundle of inputs. To measure efficiency, we use the 
stochastic frontier approach, a method developed by Aigner, Lovell and Schmidt (1977) and applied at the aggregate level notably by Adkins et al. (2002).

There are several reasons why macroeconomic productivity is better measured using this approach rather than more common measures of productivity. First, it provides a synthetic measure of productivity. Indeed, unlike basic productivity measures (e.g. per capita income), the efficiency scores computed with the stochastic frontier approach allow us to include several input dimensions in evaluating performances. As a result, output is not only compared to the labor stock, but also to both the physical and human capital stocks.

Second, it provides relative measures of productivity. Namely, a common production frontier is estimated, which allows the comparison of each country to the best-practice countries. As a result, the efficiency score assesses how close a country's actual production is to what its optimal production would be for using the same bundle of inputs. This then gives us a relative measure of productivity.

Third, whereas total factor productivity measures assess performance by the whole residual from the production frontier for each country, the stochastic frontier approach allows us to separate the distance to the production frontier into an inefficiency term and a random error, taking into account exogenous events.

After having assessed each country's level of efficiency, we may determine the interrelationship between corruption, governance and efficiency in order to test the grease the wheels versus the sand the wheels hypothesis. A natural way of estimating this relationship would be to resort to a two-stage approach. This approach would consist of first estimating efficiency scores, and then regressing them on the relevant set of explanatory variables. Although widely used in microeconomic studies, this approach is inconsistent, as it assumes in the first stage that inefficiencies are independently distributed, while the second-stage regression does not respect the independence assumption.

Consequently, we resort to the one-stage approach developed by Battese and Coelli (1995), whereby the stochastic frontier model includes a production frontier as well as an equation in which inefficiencies are specified as a function of explanatory variables. This approach is more consistent than the two-stage approach, which explains its application in studies of the determinants of technical efficiency at the aggregate level, such as Adkins et al. (2002).

Our stochastic frontier model thus includes two equations. The first one is the specification of the production frontier. We assume a constant returns-to-scale Cobb-Douglas 
production technology ${ }^{6}$, which we write as:

$$
\ln (Y / L)_{i t}=\alpha_{0}+\alpha_{1} \ln (K / L)_{i t}+\alpha_{2} \ln (H / L)_{i t}+v_{i t}-u_{i t}
$$

where $i$ indexes countries and $t$ the year of observation. $(Y / L),(K / L),(H / L)$ are output per worker, capital per worker, and human capital per worker respectively. $v_{i t}$ is a random disturbance, which reflects luck or measurement errors. It is assumed to have a normal distribution with zero mean and variance $\sigma_{v}{ }^{2} \cdot u_{i t}$ is an inefficiency term, capturing technical inefficiencies. It is a one-sided component with variance $\sigma_{u}^{2}$. As is common in the literature, we assume a half-normal distribution for the inefficiency term.

The second equation is the specification of inefficiencies as:

$$
u_{i t}=\delta z_{i t}+W_{i t}
$$

where $u_{i t}$ is country $i$ 's inefficiency, $z_{i t}$ is a $p \times 1$ vector of $p$ explanatory variables, $\delta$ is a $1 \times p$ vector of parameters to be estimated, $W_{i t}$ the random variable defined by the truncation of the normal distribution with mean zero and variance $\sigma^{2}=\sigma_{u}^{2}+\sigma_{v}^{2}$.

Finally, we use the Frontier software version 4.1 developed by Coelli (1996) to perform the maximum likelihood estimation of the stochastic frontier model.

\subsection{Testing the two competing hypotheses}

The test of the grease the wheels and the sand the wheels hypotheses that we use consists in assessing how a modification of the quality of the institutional framework affects the impact of corruption on efficiency. More precisely, the relationship between the coefficient of corruption in expression 2 and the quality of governance must be assessed. Following Méon and Sekkat (2005), we do so by including an interaction term between a corruption index and a governance index in expression (2), in addition to usual explanatory variables. The estimated relationship therefore reads:

$$
u_{i t}=\delta_{0}+\delta_{1} \operatorname{corrup}_{i}+\delta_{2} \text { corrup }_{i} \times \text { gov }_{i}+\delta_{3} \text { gov }_{i}+\delta_{c} \text { control }_{i t}+W_{i t}
$$

\footnotetext{
${ }^{6}$ When Hall and Jones (1999) estimate aggregate productivity in a related cross-country study, they find that results obtained with a Cobb-Douglas production function are very similar to the results obtained when the production function is not restricted to that specification. Kneller and Stevens (2003) reached similar conclusions when estimating aggregate efficiency frontiers.

We also adopt constant returns-to-scale because, as Moroney and Lovell (1997, p.1086) put it, "at the economywide level, constant returns-to-scale is virtually compelling".
} 
where $u_{i t}$ is country $i$ 's inefficiency, corrup $_{i}$ a measure of corruption, gov $v_{i}$ a measure of the

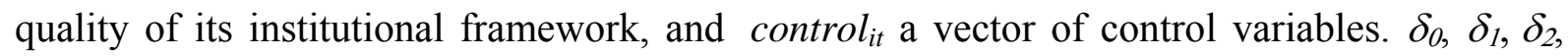
and $\delta_{3}$ are scalars, whereas $\delta_{c}$ is a vector of coefficients.

A reformulation of expression (3) shows more clearly how it can be used to test the grease the wheels and the sand the wheels hypotheses:

$$
u_{i t}=\delta_{0}+\left(\delta_{1}+\delta_{2} \times \text { gov }_{i}\right) \text { corrup }_{i}+\delta_{3} \text { gov }_{i}+\delta_{c} \text { control }_{i t}+W_{i t}
$$

In order to answer the question we address, the key parameters are $\delta_{1}$ and $\delta_{2}$. To understand why, let us first assume that the sand the wheels hypothesis holds. In this case, corruption always has a negative impact on efficiency, but that impact worsens when the institutional framework deteriorates. The coefficient of corruption must therefore always be positive but less so when the institutional framework is efficient. Accordingly, $\delta_{1}$ must be positive but $\delta_{2}$ negative. Thereby the positive impact of corruption on inefficiency is a decreasing function of the quality of the other dimensions of governance.

Let us now assume instead that the grease the wheels hypothesis holds. In this case, corruption has a positive effect on efficiency when the quality of governance is very low, but an effect that becomes negative when the quality of governance is high. Thus, it has a negative impact on inefficiency if the index of governance is close to zero. For the coefficient of corruption to be negative when $g o v_{i}$ is very small, coefficient $\delta_{1}$ must be negative. However, the "grease the wheels hypothesis" implies that inefficiency is positively correlated with corruption when governance is satisfactory, namely when gov $_{i}$ is large. $\delta_{2}$ must therefore be positive. Moreover, for the grease the wheels hypothesis to be verified, the value must be such that the overall coefficient of the corruption index $\left(\delta_{1}+\delta_{2} \times g o v_{i}\right)$ may be negative for low values of the governance parameter. That is, corruption must be negatively associated with inefficiency for at least the worst governed country.

That $\delta_{1}$ and $\delta_{2}$ bear the necessary signs does not ensure however that the grease the wheels hypothesis, as defined in the previous section, strictly holds. Instead, the value of the coefficients and the range of the relevant governance index can be such that no country in our sample will present a negative overall coefficient of corruption. In this case, the observed coefficients simply mean that corruption is detrimental everywhere but less so in countries where governance is poor. 
One may therefore observe two forms of the grease the wheels hypothesis, depending on the value of the coefficients and the range of the relevant governance index. Namely, if the relevant governance index can reach such a low level that the overall coefficient of corruption may be negative, then greater corruption can indeed reduce aggregate inefficiency in some countries. This situation will henceforth be referred to as the "strong" grease the wheels hypothesis. If, instead, no country in the sample exhibits a low enough institutional quality for the overall coefficient of corruption to become positive, then the estimated coefficients only imply that corruption is less detrimental in countries plagued by a deficient institutional framework than in other countries. Corruption however remains positively correlated with inefficiency in all countries. From now on, this result will be referred to as the "weak" grease the wheels hypothesis. In any case, one must keep in mind that even the strong form of the grease the wheels hypothesis never implies that corruption improves efficiency in all countries. In contrast, it only does in those where governance is defective enough.

\section{Data}

We use three sets of data: measures of corruption, measures of the quality of governance, and macroeconomic data. These must be described in turn.

\subsection{Corruption data}

Whereas corruption is easily defined as "the use of public office for private gains" (see e.g. Bardhan, 1997), its proper measurement is less consensual. Basically, available measures of corruption that allow cross-country comparisons fall into three broad categories. The first set of indicators uses pools of experts to assess the level of corruption that prevails in a country. More often than not, these ratings come from private risk-rating agencies, such as Business International Corporation, whose index was used by Mauro (1995) for instance. The second type of index is based on the results of surveys conducted on residents that are usually carried out by international or non-governmental organizations. The index provided by the World Economic Forum's Global Competitiveness Report, used by Wei (2000), falls into this category.

The third category consists of composite indices that aggregate those of the previous two categories. This kind of index has two main advantages. First, composite indices allow the biases of specific indices to cancel each other out, therefore determining an average opinion of corruption. This advantage is sizeable, as basic indicators may be plagued by 
important biases since they are subjective by construction. Secondly, composite indices can provide data for wider samples of countries because they aggregate several other indices thereby allowing one index to fill the gaps of another.

In this study, we use two composite indices and one survey index to assess the consequences of corruption. Each index is used in turn, both as a robustness check and to allow comparison with previous studies. Namely, we focus on the corruption index provided by the World Bank (henceforth WB), and complement our results with those obtained with the Corruption Perception Index (hereafter CPI) published by Transparency International, and the corruption index used by Wei (2000) (from now on Wei).

The CPI index is available directly from the Transparency International website. This index is simply an average of other indices. It ranges from zero, the most corrupt situation, to ten, the least so. For the sake of clarity, we used the opposite of this index in our computations so that an increase in the index can be directly interpreted as an increase in the level of corruption.

The World Bank's corruption indicator is also a composite index. However it is estimated by an unobserved component model instead of being a simple average of existing indices. ${ }^{7}$ The CPI and the WB indices also differ in the sets of basic indicators of corruption that they aggregate. ${ }^{8}$ Therefore the two indices are complement each other, since they aggregate two different sets of indicators using two different methods. ${ }^{9}$

The WB indicator can be found in the Governance database posted on the World Bank's website. It ranges from -2.5 to +2.5 . Like the CPI index, it is built so that an increase of the index reflects a better control of corruption. To transform it from an indicator of probity to an indicator of corruption, it was rescaled so as to increase with the level of corruption.

Wei (2000)'s index is an extension of the corruption index published in the World Economic Forum's Global Competitiveness Report 1997. To increase the coverage of his dataset, Wei (2000) filled the gaps left by that first index with the information provided by the World Bank's World Development Report 1997.

Finally, in order to properly compare their estimates, all three indices were rescaled so as to range from 0 to 10 .

\footnotetext{
${ }^{7}$ The construction of the World Bank's index is described in Kaufmann et al. (1999a).

8 The interested reader may find an exhaustive description of the composition of each indicator in Lambsdorff (1999) and Kaufmann et al. (1999b).

${ }^{9}$ Dreher et al. (2007) moreover found that the CPI was strongly correlated with estimates of the extent of corruption based on a structural model.
} 


\subsection{Governance data}

Like corruption, other facets of governance do not lend themselves easily to an objective evaluation. Quantitative indicators of governance therefore rest on subjective evaluations. To date, the largest and most comprehensive set of data assessing institutional quality is the data set from which our second corruption measure was extracted. Kaufmann et al. (1999a, b) classify available indicators of governance into six clusters and aggregated them into as many composite indices. ${ }^{10}$ Each composite indicator represents a different dimension of governance and ranges from -2.5 to +2.5 , higher values being associated with better governance. They were however all rescaled so as to range from 0 to 10 , where 10 corresponds to the best possible governance. Having already explained the World Bank's corruption index in the previous section, we will now simply give the definitions of the other five indicators as reported in Kaufmann et al. (1999b).

Table 2

Summary statistics on corruption and other governance variables

\begin{tabular}{|l|cccc|}
\hline Variable & Mean & $\begin{array}{c}\text { Standard } \\
\text { Deviation }\end{array}$ & Minimum & Maximum \\
\hline Corruption WB & 4.16 & 2.06 & 0.74 & 7.20 \\
Corruption CPI & 3.91 & 2.62 & 0.06 & 7.95 \\
Corruption WEI & 4.01 & 2.32 & 0.50 & 7.50 \\
Voice & 6.04 & 1.72 & 2.66 & 8.38 \\
Lackviol & 5.58 & 1.74 & 2.42 & 8.38 \\
Goveff & 5.88 & 1.86 & 2.74 & 9.16 \\
Reg & 6.10 & 0.89 & 4.32 & 7.48 \\
Rulelaw & 5.90 & 1.97 & 2.56 & 9.00 \\
\hline
\end{tabular}

Higher values of corruption indices indicate a greater prevalence of corruption, while other indices increase with the governance quality. Those statistics are computed for the sample of 54 countries.

The first pair of indicators measures aspects of governance that have been the focus of a literature devoted to assessing the impact of democracy and political stability. More precisely, Kaufmann et al. (1999a, b) "voice and accountability" indicator (Voice) measures "the extent to which citizens of a country are able to participate in the selection of governments". It accordingly assesses the openness of the political system. The "lack of

\footnotetext{
${ }^{10}$ For an example of utilization of those indices, one may either refer to Kaufmann et al. (1999b)'s original paper or Easterly and Levine (2003).
} 
political violence" indicator (Lackviol) provides an assessment of the political risk associated to a country. It "measures perceptions of the likelihood that the government in power will be destabilized or overthrown by possibly unconstitutional and/or violent means".

The second pair of indicators assesses the soundness of a country's policies and the quality of the administration that is in charge of implementing them. Accordingly, the indicator called "government effectiveness" (Goveff), concerns the "perceptions of the quality of public service provision, the quality of the bureaucracy, the competence of the civil servants, the independence of the civil service from political pressures, and the credibility of the government's commitment to policies". The "regulatory burden" indicator (Reg) captures "the incidence of market unfriendly policies such as price controls or inadequate bank supervision, as well as perceptions of the burden imposed by excessive regulation".

The final indicator provided by Kaufmann et al. (1999a, b) assesses the level of respect of citizens have for their country's legal framework. This "rule of law" indicator refers to "the extent to which agents have confidence in and abide by the rules of society" (Rulelaw). A chief component of this cluster is the enforceability of contracts.

\subsection{Macroeconomic data and control variables}

Real output per worker and labor force data are taken from the World Bank Indicators database. Real capital per worker data are provided by Nehru and Dhareshwar (1994). They were complemented after 1990 by applying the perpetual inventory method on real investment figures from the World Bank. Because they are measured in local currency at 1987 prices, and because our computations require comparisons of output and input levels, we convert them in US dollars, using the annual average exchange rate provided by the Macro time series database of the World Bank. To smooth the impact of extreme exchange rate fluctuations, we use an average of the exchange rate computed over the period 1985-1989. Human capital is proxied by the total number of years of schooling of the working-age population over 15 years old. That dataset is taken from the Barro-Lee (2000) education dataset, and can be downloaded from the Economic Growth Resources website.

Due to the limited size of our sample, the number of control variables must remain small. We restricted ourselves accordingly to three control variables that are commonly used in the literature. The first one is openness to trade. It is proxied by Sachs and Warner (1995)'s index (Openness). Although the debate on the impact of trade on growth is at least as old as economics itself, recent evidence from Edwards (1998) among others suggests that openness may be positively linked to productivity. 
The second control variable is the index of ethno-linguistic fractionalization (Ethno. Frac.). This index measures the probability that two individuals drawn at random from the population of a country do not speak the same language. Mauro (1995) or Hall and Jones (1999) for instance use this index. This variable is usually interpreted as proxying a country's sources of long-term political unrest.

As a third control variable, we consider latitude (Latitude). A negative correlation between distance from the equator and economic performance has repeatedly been reported, for instance in Sachs (2001), although no consensual explanation to this finding exists. ${ }^{11}$

We focus on the years 1994 to 1997 because 1997 is the latest for which the capital per worker ratio is available. Using the contemporaneous vintages of corruption and governance indices, we could gather a data set for a sample of up to 54 countries whose descriptive statistics are displayed in table 3. That sample features both developed and developing countries, as the range of output per worker points out.

\section{Table 3}

Summary statistics on economic and control variables

\begin{tabular}{|l|cccc|}
\hline Variable & Mean & $\begin{array}{c}\text { Standard } \\
\text { Deviation }\end{array}$ & Minimum & Maximum \\
\hline Y/L & $13,856.84$ & $14,844.14$ & 317.99 & $43,917.22$ \\
K/L & $44,392.18$ & $50,528.82$ & 819.42 & $168,891.01$ \\
H/L & 10.91 & 4.56 & 2.94 & 18.37 \\
Latitude & 27.82 & 17.76 & 0.23 & 60.21 \\
Openness & 87.96 & 30.62 & 0.00 & 1.00 \\
Ethno. Frac. & 37.96 & 30.16 & 0.00 & 90.00 \\
\hline
\end{tabular}

\section{Results}

This section presents the main results of our estimations, and provides an assessment of their significance, followed by robustness checks.

\footnotetext{
${ }^{11}$ Hall and Jones (1999) however suggest that the history of former colonies may be linked to their location. However, tropical diseases and disasters may also be responsible for that relationship.
} 


\subsection{Findings}

Tables $4 \mathrm{a}$ to $4 \mathrm{e}$ display our first set of results. In each table, we study the interaction between corruption and a different dimension of governance. For each of the three corruption indices the relationship is estimated twice, first without interaction between corruption and governance, then incorporating an interaction term. The first five lines exhibit the coefficients of the estimated production frontier, whereas the lower part of the table is devoted to the coefficients of the equation in which inefficiency is explained. ${ }^{12}$ Three year-dummies for 1994, 1995, and 1996 (respectively Year94, Year95, and Year96) were introduced to the specification of the production function to control for possible year-specific fluctuations of the frontier.

Table 4a: estimation with voice and accountability as the governance variable

\begin{tabular}{|c|c|c|c|c|c|c|}
\hline & \multicolumn{2}{|c|}{ WB } & \multicolumn{2}{|c|}{ CPI } & \multicolumn{2}{|c|}{ WEI } \\
\hline & $\begin{array}{l}\text { Without } \\
\text { interaction }\end{array}$ & $\begin{array}{c}\text { With } \\
\text { interaction }\end{array}$ & $\begin{array}{l}\text { Without } \\
\text { interaction }\end{array}$ & $\begin{array}{c}\text { With } \\
\text { interaction }\end{array}$ & $\begin{array}{l}\text { Without } \\
\text { interaction }\end{array}$ & $\begin{array}{c}\text { With } \\
\text { interaction }\end{array}$ \\
\hline & 4a.1 & 4a.2 & 4a.3 & $4 a .4$ & $4 a .5$ & 4a.6 \\
\hline Intercept & $\begin{array}{c}0.3448 \\
(0.99)\end{array}$ & $\begin{array}{c}0.8604 * * * \\
(2.63)\end{array}$ & $\begin{array}{c}1.0800 * * * \\
(3.07)\end{array}$ & $\begin{array}{c}1.1873 * * * \\
(3.70)\end{array}$ & $\begin{array}{c}-0.4353 \\
(-1.24)\end{array}$ & $\begin{array}{c}-0.2137 \\
(-0.53)\end{array}$ \\
\hline $\log (\mathrm{K} / \mathrm{L})$ & $\begin{array}{c}0.8311 * * * \\
(33.52)\end{array}$ & $\begin{array}{c}0.7858^{* * * *} \\
(35.98)\end{array}$ & $\begin{array}{c}0.8134 * * * \\
(48.92)\end{array}$ & $\begin{array}{c}0.8015 * * * \\
(42.99)\end{array}$ & $\begin{array}{c}0.8889 * * * \\
(39.70)\end{array}$ & $\begin{array}{c}0.8729 * * * \\
(30.14)\end{array}$ \\
\hline $\log (H / L)$ & $\begin{array}{c}0.1646^{* * * *} \\
(2.89)\end{array}$ & $\begin{array}{c}0.2386^{* * *} \\
(4.21)\end{array}$ & $\begin{array}{c}0.3302^{* * *} \\
\quad(4.79)\end{array}$ & $\begin{array}{c}0.3425 * * * \\
(5.62)\end{array}$ & $\begin{array}{c}0.0395 \\
(0.63)\end{array}$ & $\begin{array}{c}0.0754 \\
(1.13)\end{array}$ \\
\hline Year94 & $\begin{array}{c}-0.0065 \\
(-0.20)\end{array}$ & $\begin{array}{l}-0.0146 \\
(-0.44)\end{array}$ & $\begin{array}{c}-0.0084 \\
(-0.28)\end{array}$ & $\begin{array}{c}-0.0115 \\
(-0.40)\end{array}$ & $\begin{array}{c}-0.0017 \\
(-0.05)\end{array}$ & $\begin{array}{c}-0.0028 \\
(-0.08)\end{array}$ \\
\hline Year95 & $\begin{array}{c}-0.0025 \\
(-0.08)\end{array}$ & $\begin{array}{c}-0.0059 \\
(-0.18)\end{array}$ & $\begin{array}{c}-0.0015 \\
(-0.05)\end{array}$ & $\begin{array}{c}-0.0011 \\
(-0.04)\end{array}$ & $\begin{array}{c}0.0030 \\
(0.09)\end{array}$ & $\begin{array}{c}0.0020 \\
(0.06)\end{array}$ \\
\hline Year96 & $\begin{array}{l}0.0012 \\
(0.04)\end{array}$ & $\begin{array}{l}-0.0013 \\
(-0.04)\end{array}$ & $\begin{array}{c}0.6971^{\mathrm{E}}-3 \\
(0.02)\end{array}$ & $\begin{array}{l}0.0016 \\
(0.05)\end{array}$ & $\begin{array}{l}0.0051 \\
(0.14)\end{array}$ & $\begin{array}{c}0.0036 \\
(0.10)\end{array}$ \\
\hline Inter & $\begin{array}{l}-3.2099 \\
(-1.30)\end{array}$ & $\begin{array}{c}2.1358 * * \\
(2.04)\end{array}$ & $\begin{array}{c}-0.9301 * * * \\
(-2.69)\end{array}$ & $\begin{array}{l}-0.0096 \\
(-0.02)\end{array}$ & $\begin{array}{c}1.3793 * \\
(1.74)\end{array}$ & $\begin{array}{c}3.1050^{*} \\
(1.82)\end{array}$ \\
\hline Corruption & $\begin{array}{c}0.4025 \\
(1.57)\end{array}$ & $\begin{array}{c}-0.4517 * * \\
(-2.11)\end{array}$ & $\begin{array}{c}0.0659 * * * \\
\quad(4.24)\end{array}$ & $\begin{array}{c}-0.0504 \\
(-0.64)\end{array}$ & $\begin{array}{l}-0.1208 \\
(-1.17)\end{array}$ & $\begin{array}{c}-0.6471 \\
(-1.49)\end{array}$ \\
\hline Corruption $\times$ Voice & & $\begin{array}{c}0.1220^{* * *} \\
(2.73)\end{array}$ & & $\begin{array}{c}0.0199 \\
(1.42)\end{array}$ & & $\begin{array}{c}0.1056^{*} \\
(1.82)\end{array}$ \\
\hline Voice & $\begin{array}{l}0.3067 \\
(1.29)\end{array}$ & $\begin{array}{c}-0.5344 * * \\
(-2.38)\end{array}$ & $\begin{array}{c}0.0783 * \\
(1.87)\end{array}$ & $\begin{array}{c}-0.0942 \\
(-1.04)\end{array}$ & $\begin{array}{c}0.2203 \\
(1.53)\end{array}$ & $\begin{array}{c}-0.2748^{* * *} \\
(-2.61)\end{array}$ \\
\hline Openness & $\begin{array}{l}-0.6209 \\
(-1.27)\end{array}$ & $\begin{array}{c}-0.1929 * * \\
(-2.12)\end{array}$ & $\begin{array}{c}0.1630 * * \\
(2.43)\end{array}$ & $\begin{array}{c}0.2058 * * * \\
(2.76)\end{array}$ & $\begin{array}{c}-2.0841^{*} \\
(-1.67)\end{array}$ & $\begin{array}{c}-1.6042 \\
(-0.96)\end{array}$ \\
\hline Latitude & $\begin{array}{l}-0.0177 \\
(-1.13)\end{array}$ & $\begin{array}{c}-0.7100^{\mathrm{E}}-4 \\
(-0.02)\end{array}$ & $\begin{array}{c}-0.0048^{*} \\
(-1.84)\end{array}$ & $\begin{array}{l}0.0011 \\
(0.52)\end{array}$ & $\begin{array}{c}-0.0767 * \\
(-1.67)\end{array}$ & $\begin{array}{l}-0.0551 \\
(-1.01)\end{array}$ \\
\hline Ethno. Fraction. & $\begin{array}{c}-0.0014 \\
(-0.44)\end{array}$ & $\begin{array}{c}0.0010 \\
(0.81)\end{array}$ & $\begin{array}{c}0.0026^{* * *} \\
(2.91)\end{array}$ & $\begin{array}{c}0.0021^{* * *} \\
(3.08)\end{array}$ & $\begin{array}{l}-0.0133 \\
(-1.33)\end{array}$ & $\begin{array}{r}-0.0051 \\
(-0.48)\end{array}$ \\
\hline Sigma & $0.1274 *$ & $0.0764 * * *$ & $0.0148 * * *$ & $0.0165^{* * *}$ & $0.2790 * *$ & 0.2622 \\
\hline
\end{tabular}

\footnotetext{
${ }^{12}$ A minus sign indicates that an increase in the explanatory variable leads to less inefficiency, that is a rise in efficiency.
} 


\begin{tabular}{|l|c|c|c|c|c|c|}
\hline & $(1.90)$ & $(4.43)$ & $(3.47)$ & $(7.01)$ & $(1.98)$ & $(1.33)$ \\
\hline Log-likelihood & 65.432 & 71.547 & 104.047 & 104.520 & 50.967 & 51.398 \\
\hline LRT & & $\begin{array}{c}12.23 \\
* * *\end{array}$ & & 0.946 & & 0.862 \\
\hline $\mathrm{N}$ & 216 & 216 & 144 & 144 & 204 & 204 \\
\hline
\end{tabular}

$t$-statistics are displayed in parentheses under the coefficient estimates. ${ }^{*}, * *, * *$ denote an estimate significantly different from zero at the $10 \%, 5 \%$ or $1 \%$ level. 
Table 4b: estimation with lack of political violence as the governance variable

\begin{tabular}{|c|c|c|c|c|c|c|}
\hline & \multicolumn{2}{|c|}{ WB } & \multicolumn{2}{|c|}{$\mathrm{CPI}$} & \multicolumn{2}{|c|}{ WEI } \\
\hline & $\begin{array}{l}\text { Without } \\
\text { interaction }\end{array}$ & $\begin{array}{c}\text { With } \\
\text { interaction }\end{array}$ & $\begin{array}{l}\text { Without } \\
\text { interaction }\end{array}$ & $\begin{array}{c}\text { With } \\
\text { interaction }\end{array}$ & $\begin{array}{l}\text { Without } \\
\text { interaction }\end{array}$ & $\begin{array}{c}\text { With } \\
\text { interaction }\end{array}$ \\
\hline & $4 \mathrm{~b} .1$ & $4 \mathrm{~b} .2$ & $4 \mathrm{~b} .3$ & $4 \mathrm{~b} .4$ & $4 \mathrm{~b} .5$ & $4 \mathrm{~b} .6$ \\
\hline Intercept & $\begin{array}{c}0.4514 \\
(1.23)\end{array}$ & $\begin{array}{c}0.9096 * * * \\
(2.82)\end{array}$ & $\begin{array}{c}0.8233 * * \\
(2.38)\end{array}$ & $\begin{array}{c}1.2109 * * * \\
(3.67)\end{array}$ & $\begin{array}{c}-0.5863^{*} \\
(-1.90)\end{array}$ & $\begin{array}{c}0.5091 \\
(1.36)\end{array}$ \\
\hline $\log (\mathrm{K} / \mathrm{L})$ & $\begin{array}{c}0.8156^{* * *} \\
(30.35)\end{array}$ & $\begin{array}{c}0.7674 * * * \\
(38.43)\end{array}$ & $\begin{array}{c}0.8169 * * * \\
(47.35)\end{array}$ & $\begin{array}{c}0.7857^{* * * *} \\
(44.07)\end{array}$ & $\begin{array}{c}0.8947 * * * \\
(45.31)\end{array}$ & $\begin{array}{c}0.8081 * * * \\
(31.39)\end{array}$ \\
\hline $\log (H / L)$ & $\begin{array}{c}0.1659 * * * \\
\quad(2.85)\end{array}$ & $\begin{array}{c}0.2314 * * * \\
\quad(4.06)\end{array}$ & $\begin{array}{c}0.2745^{* * *} \\
(4.22)\end{array}$ & $\begin{array}{c}0.3342^{* * *} \\
(5.25)\end{array}$ & $\begin{array}{c}0.0114 \\
(0.21)\end{array}$ & $\begin{array}{c}0.1802 * * * \\
\quad(2.91)\end{array}$ \\
\hline Year94 & $\begin{array}{l}-0.0121 \\
(-0.38)\end{array}$ & $\begin{array}{c}-0.0146 \\
(-0.45)\end{array}$ & $\begin{array}{l}-0.0085 \\
(-0.28)\end{array}$ & $\begin{array}{c}-0.0044 \\
(-0.15)\end{array}$ & $\begin{array}{c}0.0010 \\
(0.03)\end{array}$ & $\begin{array}{c}-0.0115 \\
(-0.34)\end{array}$ \\
\hline Year95 & $\begin{array}{l}-0.0052 \\
(-0.17)\end{array}$ & $\begin{array}{l}-0.0065 \\
(-0.20)\end{array}$ & $\begin{array}{c}-0.7048^{E}-3 \\
(-0.02)\end{array}$ & $\begin{array}{l}0.3824^{\mathrm{E}}-4 \\
(0.13 \mathrm{E}-2)\end{array}$ & $\begin{array}{l}0.0022 \\
(0.07)\end{array}$ & $\begin{array}{c}-0.0064 \\
(-0.19)\end{array}$ \\
\hline Year96 & $\begin{array}{c}-0.4051^{\mathrm{E}}-3 \\
(-0.01)\end{array}$ & $\begin{array}{c}-0.0016 \\
(-0.05) \\
\end{array}$ & $\begin{array}{c}0.5146^{\mathrm{E}}-3 \\
(0.02)\end{array}$ & $\begin{array}{l}0.0076 \\
(0.26) \\
\end{array}$ & $\begin{array}{l}0.0031 \\
(0.09) \\
\end{array}$ & $\begin{array}{l}0.0015 \\
(0.05) \\
\end{array}$ \\
\hline Intercept & $\begin{array}{l}-1.1353 \\
(-1.34)\end{array}$ & $\begin{array}{c}2.0539 * * \\
(2.28)\end{array}$ & $\begin{array}{c}-0.6110 * * * \\
(-3.20)\end{array}$ & $\begin{array}{l}0.2931 \\
(0.72)\end{array}$ & $\begin{array}{c}4.6206^{* * *} \\
(2.24)\end{array}$ & $\begin{array}{c}3.8438 * * * \\
(3.56)\end{array}$ \\
\hline Corruption & $\begin{array}{c}0.2208 * * \\
(2.15)\end{array}$ & $\begin{array}{c}-0.3446^{* *} \\
(-2.23)\end{array}$ & $\begin{array}{c}0.0601 * * * \\
(3.92)\end{array}$ & $\begin{array}{c}-0.0542 \\
(-0.93)\end{array}$ & $\begin{array}{c}-0.3515^{*} \\
(-1.86)\end{array}$ & $\begin{array}{c}-0.5839 * * * \\
(-2.86)\end{array}$ \\
\hline Corruption $\times$ Lackviol & & $\begin{array}{c}0.1002 * * * \\
\quad(3.24)\end{array}$ & & $\begin{array}{c}0.0209 * \\
(1.87)\end{array}$ & & $\begin{array}{c}0.1127 * * * \\
\quad(2.86)\end{array}$ \\
\hline Lackviol & $\begin{array}{l}0.1008 \\
(1.52)\end{array}$ & $\begin{array}{c}-0.4692 * * * \\
(-2.73)\end{array}$ & $\begin{array}{l}0.0091 \\
(0.54)\end{array}$ & $\begin{array}{c}-0.1241 * \\
(-1.75)\end{array}$ & $\begin{array}{c}-0.3496^{* *} \\
(-2.19)\end{array}$ & $\begin{array}{c}-0.6313 * * * \\
(-3.02)\end{array}$ \\
\hline Openness & $\begin{array}{c}-0.3384^{*} \\
(-1.80)\end{array}$ & $\begin{array}{c}-0.1703 * \\
(-1.87)\end{array}$ & $\begin{array}{c}0.2091 * * * \\
(4.22)\end{array}$ & $\begin{array}{c}0.1471 * * \\
(2.35)\end{array}$ & $\begin{array}{c}-1.4482 * * \\
(-2.25)\end{array}$ & $\begin{array}{c}-0.2922 * * * \\
(-2.71)\end{array}$ \\
\hline Latitude & $\begin{array}{l}-0.0091 \\
(-1.34)\end{array}$ & $\begin{array}{c}-0.0052 \\
(-1.58)\end{array}$ & $\begin{array}{c}0.6081^{\mathrm{E}}-3 \\
(0.36)\end{array}$ & $\begin{array}{c}-0.9156^{\mathrm{E}}-3 \\
(-0.51)\end{array}$ & $\begin{array}{c}-0.0577 * * \\
(-2.19)\end{array}$ & $\begin{array}{c}-0.0104 * * \\
(-2.46)\end{array}$ \\
\hline Ethno. Fraction. & $\begin{array}{c}-0.9100^{\mathrm{E}}-3 \\
(-0.49)\end{array}$ & $\begin{array}{l}0.0007 \\
(0.49)\end{array}$ & $\begin{array}{c}0.0024 * * * \\
(3.66)\end{array}$ & $\begin{array}{c}0.0018^{* *} \\
(2.29)\end{array}$ & $\begin{array}{c}-0.0113^{*} \\
(-1.86)\end{array}$ & $\begin{array}{c}-0.1589^{\mathrm{E}}-3 \\
(-0.12)\end{array}$ \\
\hline Sigma & $\begin{array}{c}0.0991 * * \\
(2.28) \\
\end{array}$ & $\begin{array}{c}0.0647 * * * \\
(5.35)\end{array}$ & $\begin{array}{c}0.0147 * * * \\
(5.09) \\
\end{array}$ & $\begin{array}{c}0.0172^{* * *} \\
(7.69) \\
\end{array}$ & $\begin{array}{c}0.2465 * * * \\
(3.02)\end{array}$ & $\begin{array}{c}0.0742 * * * \\
(6.07) \\
\end{array}$ \\
\hline Log-likelihood & 61.720 & 69.292 & 102.387 & 104.858 & 52.093 & 63.869 \\
\hline LRT & & $\begin{array}{c}15.14 \\
* * *\end{array}$ & & $\begin{array}{c}4.94 \\
* *\end{array}$ & & $\begin{array}{c}23.55 \\
* * *\end{array}$ \\
\hline $\mathrm{N}$ & 216 & 216 & 144 & 144 & 204 & 204 \\
\hline
\end{tabular}

$t$-statistics are displayed in parentheses under the coefficient estimates. $*$, **, *** denote an estimate significantly different from zero at the $10 \%, 5 \%$ or $1 \%$ level. 
Table 4c: estimation with government efficiency as the governance variable

\begin{tabular}{|c|c|c|c|c|c|c|}
\hline & \multicolumn{2}{|c|}{ WB } & \multicolumn{2}{|c|}{ CPI } & \multicolumn{2}{|c|}{ WEI } \\
\hline & $\begin{array}{c}\text { Without } \\
\text { interaction }\end{array}$ & $\begin{array}{c}\text { With } \\
\text { interaction }\end{array}$ & $\begin{array}{c}\text { Without } \\
\text { interaction }\end{array}$ & $\begin{array}{c}\text { With } \\
\text { interaction }\end{array}$ & $\begin{array}{c}\text { Without } \\
\text { interaction }\end{array}$ & $\begin{array}{c}\text { With } \\
\text { interaction }\end{array}$ \\
\hline & $4 c .1$ & 4c. 2 & $4 c .3$ & $4 c .4$ & $4 c .5$ & $4 c .6$ \\
\hline Intercept & $\begin{array}{c}0.1719 \\
(0.50)\end{array}$ & $\begin{array}{c}0.4516 \\
(1.30)\end{array}$ & $\begin{array}{c}0.6992 * * \\
(2.06)\end{array}$ & $\begin{array}{c}0.9436^{* * *} \\
(2.90)\end{array}$ & $\begin{array}{c}-0.3056 \\
(-0.80)\end{array}$ & $\begin{array}{c}0.6036^{*} \\
(1.67)\end{array}$ \\
\hline $\log (\mathrm{K} / \mathrm{L})$ & $\begin{array}{c}0.8283 * * * \\
(34.70)\end{array}$ & $\begin{array}{c}0.7951 * * * \\
(34.96)\end{array}$ & $\begin{array}{c}0.8199 * * * \\
(46.05)\end{array}$ & $\begin{array}{c}0.8000 * * * \\
(47.22)\end{array}$ & $\begin{array}{c}0.8573 * * * \\
(29.20)\end{array}$ & $\begin{array}{c}0.7864 * * * \\
(31.08)\end{array}$ \\
\hline $\log (\mathrm{H} / \mathrm{L})$ & $\begin{array}{c}0.1162 * * \\
(2.02)\end{array}$ & $\begin{array}{c}0.1526^{* *} \\
(2.55)\end{array}$ & $\begin{array}{c}0.2487 * * * \\
\quad(3.90)\end{array}$ & $\begin{array}{c}0.2874 * * * \\
(4.65)\end{array}$ & $\begin{array}{c}0.0408 \\
(0.68)\end{array}$ & \begin{tabular}{|c}
$0.1797 * * *$ \\
$(2.88)$
\end{tabular} \\
\hline Year94 & $\begin{array}{l}-0.0128 \\
(-0.40)\end{array}$ & $\begin{array}{l}-0.0155 \\
(-0.46)\end{array}$ & $\begin{array}{l}-0.0085 \\
(-0.28)\end{array}$ & $\begin{array}{l}-0.0124 \\
(-0.42)\end{array}$ & $\begin{array}{c}-0.0061 \\
(-0.19)\end{array}$ & $\begin{array}{c}-0.0136 \\
(-0.37)\end{array}$ \\
\hline Year95 & $\begin{array}{l}-0.0048 \\
(-0.15)\end{array}$ & $\begin{array}{l}-0.0050 \\
(-0.15)\end{array}$ & $\begin{array}{l}-0.0017 \\
(-0.05)\end{array}$ & $\begin{array}{l}-0.0021 \\
(-0.07)\end{array}$ & $\begin{array}{c}0.4378^{\mathrm{E}}-3 \\
(0.01)\end{array}$ & $\begin{array}{c}-0.0134 \\
(-0.37)\end{array}$ \\
\hline Year96 & $\begin{array}{c}-0.7773^{\mathrm{E}}-3 \\
(-0.02) \\
\end{array}$ & $\begin{array}{c}0.2914^{\mathrm{E}}-3 \\
(0.01)\end{array}$ & $\begin{array}{c}-0.2176^{\mathrm{E}}-3 \\
(-0.01)\end{array}$ & $\begin{array}{c}0.9863^{\mathrm{E}}-3 \\
(0.03)\end{array}$ & $\begin{array}{l}0.0018 \\
(0.05)\end{array}$ & $\begin{array}{l}0.0039 \\
(0.11) \\
\end{array}$ \\
\hline Inte & $\begin{array}{c}2.0598 * * * \\
(2.86)\end{array}$ & $\begin{array}{c}3.9650 * * * \\
(4.71)\end{array}$ & $\begin{array}{c}-0.1276 \\
(-0.50)\end{array}$ & $\begin{array}{c}0.4688 \\
(1.14)\end{array}$ & $\begin{array}{c}2.1086^{* * *} \\
(2.67)\end{array}$ & $\begin{array}{c}3.3328^{* * * *} \\
(9.66)\end{array}$ \\
\hline Corruption & $\begin{array}{l}-0.0946 \\
(-1.35)\end{array}$ & $\begin{array}{c}-0.4692 * * * \\
(-3.43)\end{array}$ & $\begin{array}{c}0.0291 \\
(1.45)\end{array}$ & $\begin{array}{c}-0.0430 \\
(-0.78)\end{array}$ & $\begin{array}{l}-0.1103 \\
(-1.36)\end{array}$ & $\begin{array}{c}-0.4425 * * * \\
(-5.38)\end{array}$ \\
\hline Corru & & $\begin{array}{c}0.0765^{* * * *} \\
(3.00)\end{array}$ & & $\begin{array}{l}0.0090 \\
(1.10)\end{array}$ & & $\begin{array}{c}0.0821 * * * \\
(4.44)\end{array}$ \\
\hline Gove & $\begin{array}{c}-0.2755^{* * *} * \\
(-2.70)\end{array}$ & $\begin{array}{c}-0.6426 * * * \\
(-4.35)\end{array}$ & $\begin{array}{c}-0.0565^{* *} \\
(-2.02)\end{array}$ & $\begin{array}{c}-0.1132 * * \\
(-2.09)\end{array}$ & $\begin{array}{c}-0.3078^{* *} \\
(-2.55)\end{array}$ & $\begin{array}{c}-0.5848^{* * *} \\
(-7.20)\end{array}$ \\
\hline Openness & $\begin{array}{l}-0.0991 \\
(-0.99)\end{array}$ & $\begin{array}{l}-0.0614 \\
(-0.52)\end{array}$ & $\begin{array}{c}0.2473 * * * \\
\quad(4.68)\end{array}$ & $\begin{array}{c}0.1711^{* * * *} \\
(3.00)\end{array}$ & $\begin{array}{c}-0.0935 \\
(-0.92)\end{array}$ & $\begin{array}{c}-0.0622 \\
(-0.61)\end{array}$ \\
\hline Latitude & $\begin{array}{l}-0.0056 \\
(-1.27)\end{array}$ & $\begin{array}{l}-0.0025 \\
(-0.67)\end{array}$ & $\begin{array}{l}0.0014 \\
(1.01)\end{array}$ & $\begin{array}{c}0.6880^{\mathrm{E}}-4 \\
(0.05)\end{array}$ & $\begin{array}{l}-0.0061 \\
(-0.83)\end{array}$ & $\begin{array}{c}0.2159^{\mathrm{E}}-3 \\
(0.06)\end{array}$ \\
\hline Ethno. Fraction. & $\begin{array}{c}0.5410^{\mathrm{E}}-3 \\
(0.35)\end{array}$ & $\begin{array}{c}0.7762^{\mathrm{E}}-3 \\
(0.51)\end{array}$ & $\begin{array}{c}0.0023 * * * \\
(3.23)\end{array}$ & $\begin{array}{c}0.0021^{* * *} \\
(3.39)\end{array}$ & $\begin{array}{l}0.0017 \\
(0.97)\end{array}$ & $\begin{array}{c}0.0010^{\mathrm{E}}-2 \\
(0.79)\end{array}$ \\
\hline Sigma & $\begin{array}{c}0.0768 * * * \\
(3.05) \\
\end{array}$ & $\begin{array}{c}0.0632 * * * \\
(5.57)\end{array}$ & $\begin{array}{c}0.0138^{* * * *} \\
(5.24)\end{array}$ & $\begin{array}{c}0.0136^{* * * *} \\
(5.52)\end{array}$ & $\begin{array}{c}0.0685^{* * *} * \\
(3.14)\end{array}$ & $\begin{array}{c}0.0589 * * * \\
(4.37)\end{array}$ \\
\hline $\log -1$ & 69.453 & 75.544 & 105.264 & 105.175 & 71.803 & 80.853 \\
\hline LRT & & $\begin{array}{c}12.18 \\
* * *\end{array}$ & & -0.178 & & $\begin{array}{c}18.09 \\
* * *\end{array}$ \\
\hline $\mathrm{N}$ & 16 & 216 & 144 & 144 & 204 & 204 \\
\hline
\end{tabular}

$t$-statistics are displayed in parentheses under the coefficient estimates. $*$, **, *** denote an estimate significantly different from zero at the $10 \%, 5 \%$ or $1 \%$ level. 
Table 4d: estimation with quality of the regulatory framework as the governance variable

\begin{tabular}{|c|c|c|c|c|c|c|}
\hline & \multicolumn{2}{|c|}{ WB } & \multicolumn{2}{|c|}{$\mathrm{CPI}$} & \multicolumn{2}{|c|}{ WEI } \\
\hline & $\begin{array}{l}\text { Without } \\
\text { interaction }\end{array}$ & $\begin{array}{c}\text { With } \\
\text { interaction }\end{array}$ & $\begin{array}{l}\text { Without } \\
\text { interaction }\end{array}$ & $\begin{array}{c}\text { With } \\
\text { interaction }\end{array}$ & $\begin{array}{l}\text { Without } \\
\text { interaction }\end{array}$ & $\begin{array}{c}\text { With } \\
\text { interaction }\end{array}$ \\
\hline & $4 \mathrm{~d} .1$ & $4 \mathrm{~d} .2$ & $4 \mathrm{~d} .3$ & $4 \mathrm{~d} .4$ & $4 \mathrm{~d} .5$ & $4 \mathrm{~d} .6$ \\
\hline Intercept & $\begin{array}{c}0.4084 \\
(1.08)\end{array}$ & $\begin{array}{c}0.6082 * \\
(1.91)\end{array}$ & $\begin{array}{c}0.8264 * * \\
(2.31)\end{array}$ & $\begin{array}{c}0.9124 * * * \\
(2.87)\end{array}$ & $\begin{array}{c}-0.4409 \\
(-1.48)\end{array}$ & $\begin{array}{c}0.4863 \\
(1.02)\end{array}$ \\
\hline $\log (\mathrm{K} / \mathrm{L})$ & $\begin{array}{c}0.8201 * * * \\
(29.67)\end{array}$ & $\begin{array}{c}0.8027 * * * \\
(34.74)\end{array}$ & $\begin{array}{c}0.8158 * * * \\
(43.52)\end{array}$ & $\begin{array}{c}0.8192 * * * \\
(42.95)\end{array}$ & $\begin{array}{c}0.8877 * * * \\
(48.96)\end{array}$ & $\begin{array}{c}0.8155^{* * *} * \\
(22.84)\end{array}$ \\
\hline $\log (\mathrm{H} / \mathrm{L})$ & $\begin{array}{c}0.1633 * * * \\
(2.72)\end{array}$ & $\begin{array}{c}0.1945^{* * *} * \\
(3.66)\end{array}$ & $\begin{array}{c}0.2718^{* * *} \\
(4.10)\end{array}$ & $\begin{array}{c}0.2962 * * * \\
(4.94)\end{array}$ & $\begin{array}{c}0.0364 \\
(0.68)\end{array}$ & $\begin{array}{c}0.1720^{* *} \\
(2.31)\end{array}$ \\
\hline Year94 & $\begin{array}{c}-0.0087 \\
(-0.27)\end{array}$ & $\begin{array}{c}-0.0108 \\
(0.34)\end{array}$ & $\begin{array}{c}-0.0113 \\
(-0.39)\end{array}$ & $\begin{array}{c}-0.0107 \\
(-0.37)\end{array}$ & $\begin{array}{l}-0.0021 \\
(-0.06)\end{array}$ & $\begin{array}{c}-0.0132 \\
(-0.38)\end{array}$ \\
\hline Year95 & $\begin{array}{c}-0.0036 \\
(-0.11)\end{array}$ & $\begin{array}{c}-0.0048 \\
(-0.15)\end{array}$ & $\begin{array}{c}-0.0038 \\
(-0.13)\end{array}$ & $\begin{array}{c}-0.0016 \\
(-0.05)\end{array}$ & $\begin{array}{l}0.0015 \\
(0.04)\end{array}$ & $\begin{array}{r}-0.0047 \\
(-0.14)\end{array}$ \\
\hline Year96 & $\begin{array}{c}0.6311^{\mathrm{E}}-3 \\
(0.02)\end{array}$ & $\begin{array}{c}-0.1495^{\mathrm{E}}-3 \\
\left(-0.48^{\mathrm{E}}-2\right) \\
\end{array}$ & $\begin{array}{c}-0.0031 \\
(-0.11) \\
\end{array}$ & $\begin{array}{c}0.5759^{\mathrm{E}}-3 \\
(0.02)\end{array}$ & $\begin{array}{l}0.0022 \\
(0.07) \\
\end{array}$ & $\begin{array}{c}0.2607^{\mathrm{E}}-4 \\
\left(0.78^{\mathrm{E}}-3\right) \\
\end{array}$ \\
\hline Intercept & $\begin{array}{c}-1.6603 \\
(-1.27)\end{array}$ & $\begin{array}{c}4.6520^{*} \\
(1.65)\end{array}$ & $\begin{array}{c}-0.4493 * \\
(-1.69)\end{array}$ & $\begin{array}{l}1.5749 \\
(1.57)\end{array}$ & $\begin{array}{c}3.4951^{*} \\
(1.83)\end{array}$ & $\begin{array}{c}3.8040^{* *} \\
(2.14)\end{array}$ \\
\hline Corruption & $\begin{array}{c}0.2306^{*} \\
(1.77)\end{array}$ & $\begin{array}{c}-0.8768 \\
(1.62)\end{array}$ & $\begin{array}{c}0.0568 * * * \\
(3.69)\end{array}$ & $\begin{array}{c}-0.2711 * \\
(-1.72)\end{array}$ & $\begin{array}{c}-0.1783 \\
(-1.56)\end{array}$ & $\begin{array}{c}-0.6534^{*} \\
(-1.83)\end{array}$ \\
\hline Corruption $\times$ Reg & & $\begin{array}{c}0.1781^{*} \\
(1.79)\end{array}$ & & $\begin{array}{c}0.0496^{* *} \\
(2.05)\end{array}$ & & $\begin{array}{c}0.1138^{*} \\
(1.91)\end{array}$ \\
\hline Reg & $\begin{array}{l}0.1654 \\
(1.39)\end{array}$ & $\begin{array}{c}-0.8530^{*} \\
(-1.66)\end{array}$ & $\begin{array}{c}-0.0274 \\
(-0.71)\end{array}$ & $\begin{array}{c}-0.2991 * * \\
(-2.03)\end{array}$ & $\begin{array}{c}-0.1548^{*} \\
(-1.80)\end{array}$ & $\begin{array}{c}-0.5582 * \\
(-1.85)\end{array}$ \\
\hline Openness & $\begin{array}{c}-0.5027 \\
(-1.51)\end{array}$ & $\begin{array}{c}-0.4194 * * \\
(2.13)\end{array}$ & $\begin{array}{c}0.2587 * * * \\
(3.53)\end{array}$ & $\begin{array}{l}0.1242 \\
(1.33)\end{array}$ & $\begin{array}{l}-1.8285 \\
(-1.49)\end{array}$ & $\begin{array}{c}-0.4147^{* *} \\
(-2.26)\end{array}$ \\
\hline Latitude & $\begin{array}{c}-0.0086 \\
(-1.07)\end{array}$ & $\begin{array}{c}-0.0056 \\
(1.35)\end{array}$ & $\begin{array}{c}0.0012 \\
(0.80)\end{array}$ & $\begin{array}{c}-0.6184^{\mathrm{E}}-5 \\
\left(-0.41^{\mathrm{E}}-2\right)\end{array}$ & $\begin{array}{c}-0.0735^{*} \\
(-1.66)\end{array}$ & $\begin{array}{c}-0.0110 \\
(-1.63)\end{array}$ \\
\hline Ethno. Fraction. & $\begin{array}{c}-0.7423^{\mathrm{E}}-3 \\
(-0.31)\end{array}$ & $\begin{array}{c}0.5867^{\mathrm{E}}-4 \\
(0.04)\end{array}$ & $\begin{array}{c}0.0026^{* * * *} \\
(3.46)\end{array}$ & $\begin{array}{c}0.0017^{* * *} \\
(2.74)\end{array}$ & $\begin{array}{l}-0.0157 \\
(-1.10)\end{array}$ & $\begin{array}{c}0.4229^{\mathrm{E}}-3 \\
(0.25)\end{array}$ \\
\hline Sigma & $\begin{array}{c}0.1139 * \\
(1.83)\end{array}$ & $\begin{array}{c}0.1008^{* * * *} \\
(2.57)\end{array}$ & $\begin{array}{c}0.0152 * * * \\
(3.97)\end{array}$ & $\begin{array}{c}0.0150 * * * \\
(5.99)\end{array}$ & $\begin{array}{c}0.3078 * * \\
(2.09)\end{array}$ & $\begin{array}{c}0.1074 * * \\
(2.45)\end{array}$ \\
\hline Log-likelihood & 61.681 & 66.156 & 101.876 & 104.831 & 50.226 & 53.257 \\
\hline LRT & & $\begin{array}{l}8.95 \\
* * *\end{array}$ & & $\begin{array}{l}5.91 \\
* *\end{array}$ & & $\begin{array}{c}6.06 \\
* *\end{array}$ \\
\hline $\mathrm{N}$ & 216 & 216 & 144 & 144 & 204 & 204 \\
\hline
\end{tabular}

$t$-statistics are displayed in parentheses under the coefficient estimates. $*, * *, * * *$ denote an estimate significantly different from zero at the $10 \%, 5 \%$ or $1 \%$ level. 
Table 4e: estimation with the rule of law as the governance variable

\begin{tabular}{|c|c|c|c|c|c|c|}
\hline & \multicolumn{2}{|c|}{ WB } & \multicolumn{2}{|c|}{ CPI } & \multicolumn{2}{|c|}{ WEI } \\
\hline & $\begin{array}{l}\text { Without } \\
\text { interaction }\end{array}$ & $\begin{array}{c}\text { With } \\
\text { interaction }\end{array}$ & $\begin{array}{l}\text { Without } \\
\text { interaction }\end{array}$ & $\begin{array}{c}\text { With } \\
\text { interaction }\end{array}$ & $\begin{array}{l}\text { Without } \\
\text { interaction }\end{array}$ & $\begin{array}{c}\text { With } \\
\text { interaction }\end{array}$ \\
\hline & $4 \mathrm{e} .1$ & $4 \mathrm{e} .2$ & $4 \mathrm{e} .3$ & $4 \mathrm{e} .4$ & $4 \mathrm{e} .5$ & $4 \mathrm{e} .6$ \\
\hline Intercept & $\begin{array}{c}-0.1522 \\
(-0.47)\end{array}$ & $\begin{array}{c}0.5541^{*} \\
(1.66)\end{array}$ & $\begin{array}{c}0.8085^{* *} \\
(2.26)\end{array}$ & $\begin{array}{c}1.1026 * * * \\
(3.31)\end{array}$ & $\begin{array}{c}-0.6727 * * \\
(-2.43)\end{array}$ & $\begin{array}{c}0.2191 \\
(0.64)\end{array}$ \\
\hline $\log (\mathrm{K} / \mathrm{L})$ & $\begin{array}{c}0.8586^{* * *} \\
(41.35)\end{array}$ & $\begin{array}{c}0.7917 * * * \\
(38.92)\end{array}$ & $\begin{array}{c}0.8163 * * * \\
(40.06)\end{array}$ & $\begin{array}{c}0.7849 * * * \\
(40.84)\end{array}$ & $\begin{array}{c}0.8849 * * * \\
(54.16)\end{array}$ & $\begin{array}{c}0.8064 * * * \\
(35.22)\end{array}$ \\
\hline $\log (H / L)$ & $\begin{array}{c}0.0768 \\
(1.36)\end{array}$ & $\begin{array}{c}0.1743^{* * * *} \\
(2.96)\end{array}$ & $\begin{array}{c}0.2701 * * * \\
(4.09)\end{array}$ & $\begin{array}{c}0.3056^{* * *} \\
(4.70)\end{array}$ & $\begin{array}{c}-0.0075 \\
(-0.15)\end{array}$ & $\begin{array}{c}0.1146^{* *} \\
(1.96)\end{array}$ \\
\hline Year94 & $\begin{array}{c}-0.0037 \\
(-0.11)\end{array}$ & $\begin{array}{c}-0.0136 \\
(-0.43)\end{array}$ & $\begin{array}{c}-0.0094 \\
(-0.31)\end{array}$ & $\begin{array}{l}-0.0157 \\
(-0.52)\end{array}$ & $\begin{array}{c}0.0034 \\
(0.11)\end{array}$ & $\begin{array}{c}-0.4305^{\mathrm{E}}-3 \\
(-0.01)\end{array}$ \\
\hline Year95 & $\begin{array}{l}-0.1141^{\mathrm{E}}-4 \\
(-0.36 \mathrm{E}-3)\end{array}$ & $\begin{array}{c}-0.0062 \\
(-0.20)\end{array}$ & $\begin{array}{c}-0.0014 \\
(-0.05)\end{array}$ & $\begin{array}{c}-0.0038 \\
(-0.13)\end{array}$ & $\begin{array}{c}0.0058 \\
(0.19)\end{array}$ & $\begin{array}{c}0.0059 \\
(0.18)\end{array}$ \\
\hline Year96 & $\begin{array}{c}0.2292^{\mathrm{E}}-2 \\
(0.07)\end{array}$ & $\begin{array}{c}-0.0012 \\
(-0.04)\end{array}$ & $\begin{array}{c}0.6370^{\mathrm{E}}-3 \\
(0.02)\end{array}$ & $\begin{array}{l}0.0017 \\
(0.06)\end{array}$ & $\begin{array}{l}0.0062 \\
(0.20)\end{array}$ & $\begin{array}{c}0.0170 \\
(0.54)\end{array}$ \\
\hline Intercept & $\begin{array}{l}3.5793 \\
(1.46)\end{array}$ & $\begin{array}{c}3.9667 * * * \\
(4.85)\end{array}$ & $\begin{array}{l}-0.3101 \\
(-1.27)\end{array}$ & $\begin{array}{c}1.0963^{*} \\
(1.94)\end{array}$ & $\begin{array}{c}3.2598 * * * \\
(8.18)\end{array}$ & $\begin{array}{c}3.8128 * * * \\
(10.40)\end{array}$ \\
\hline Corruption & $\begin{array}{c}-0.1834 \\
(-0.86)\end{array}$ & $\begin{array}{c}-0.5261 * * * \\
(-3.83)\end{array}$ & $\begin{array}{c}0.0385^{* *} * \\
(2.01)\end{array}$ & $\begin{array}{c}-0.1390 * \\
(-1.84)\end{array}$ & $\begin{array}{c}-0.2117 * * * \\
(-5.68)\end{array}$ & $\begin{array}{c}-0.5197 * * * \\
(-7.61)\end{array}$ \\
\hline Corruption $\times$ Rulelaw & & $\begin{array}{c}0.0961^{* * *} \\
(3.68)\end{array}$ & & $\begin{array}{c}0.0283 * * \\
(2.37)\end{array}$ & & $\begin{array}{c}0.0951 * * * \\
(6.57)\end{array}$ \\
\hline Rulelaw & $\begin{array}{r}-0.4717 \\
(-1.63)\end{array}$ & $\begin{array}{c}-0.6599 * * * \\
(-4.54)\end{array}$ & $\begin{array}{l}-0.0278 \\
(-1.23)\end{array}$ & $\begin{array}{c}-0.1985^{* *} \\
(-2.44)\end{array}$ & $\begin{array}{c}-0.4664 * * * \\
(-5.77)\end{array}$ & $\begin{array}{c}-0.6396 * * * \\
(-8.02)\end{array}$ \\
\hline Openness & $\begin{array}{c}-0.7549^{*} \\
(-1.70)\end{array}$ & $\begin{array}{c}-0.1813^{*} \\
(-1.76)\end{array}$ & $\begin{array}{c}0.2148 * * * \\
(3.82)\end{array}$ & $\begin{array}{l}0.0721 \\
(1.39)\end{array}$ & $\begin{array}{c}-0.4396 * * * \\
(-3.72)\end{array}$ & $\begin{array}{l}-0.1255 \\
(-1.52)\end{array}$ \\
\hline Latitude & $\begin{array}{c}-0.0136 \\
(-1.24)\end{array}$ & $\begin{array}{c}-0.0019 \\
(-0.51)\end{array}$ & $\begin{array}{c}0.0010 \\
(0.77)\end{array}$ & $\begin{array}{c}-0.0015 \\
(-0.97)\end{array}$ & $\begin{array}{c}0.0054 \\
(0.94)\end{array}$ & $\begin{array}{c}-0.0014 \\
(-0.37)\end{array}$ \\
\hline Ethno. Fraction. & $\begin{array}{c}-0.0028 \\
(-0.69)\end{array}$ & $\begin{array}{c}0.2441^{\mathrm{E}}-3 \\
(0.17)\end{array}$ & $\begin{array}{c}0.0025^{* * * *} \\
(3.37)\end{array}$ & $\begin{array}{c}0.0013^{*} \\
(1.75)\end{array}$ & $\begin{array}{c}0.7511^{\mathrm{E}}-4 \\
(0.05)\end{array}$ & $\begin{array}{c}0.3705^{\mathrm{E}}-3 \\
(0.30)\end{array}$ \\
\hline Sigma & $\begin{array}{c}0.1622 * \\
(1.90)\end{array}$ & $\begin{array}{c}0.0683 * * * \\
(6.02)\end{array}$ & $\begin{array}{c}0.0146^{* * *} \\
(4.62) \\
\end{array}$ & $\begin{array}{c}0.0157 * * * \\
(5.70)\end{array}$ & $\begin{array}{c}0.0568 * * * \\
(6.52)\end{array}$ & $\begin{array}{c}0.0562 * * * \\
(4.48) \\
\end{array}$ \\
\hline $\log -1$ & 63.627 & 74.518 & 102.536 & 105.398 & 76.729 & 90.275 \\
\hline LRT & & $\begin{array}{c}21,78 \\
* * *\end{array}$ & & $\begin{array}{c}5,72 \\
* *\end{array}$ & & $\begin{array}{c}27,09 \\
* * *\end{array}$ \\
\hline $\mathrm{N}$ & 216 & 216 & 144 & 144 & 204 & 204 \\
\hline
\end{tabular}

$t$-statistics are displayed in parentheses under the coefficient estimates. $*$, **, *** denote an estimate significantly different from zero at the $10 \%, 5 \%$ or $1 \%$ level.

At first glance, the estimated production frontiers are stable across estimations. Moreover, estimated coefficients are similar to those reported in the literature, as for instance in Kneller and Stevens (2003). Year-dummies never exhibit a significant coefficient, which suggests that no major shift of the frontier was observed for the years featured in our study. 
In addition, all control variables are either intuitively signed or insignificant. Thus the openness index is usually correctly signed and often significant. The only exception appears with the CPI, where openness can bear a positive and significant sign, although not in all regressions, and in particular not in those that feature the interaction term between the CPI and governance. The relationship between inefficiency and latitude is less surprising. As expected, the sign of its coefficient is either insignificant or negative, implying that inefficiency ceteris paribus tends to decrease as one moves away from the equator. Finally, ethnic fractionalization is more robust than latitude, as it is positively and significantly associated with inefficiency in eleven estimations. Accordingly, more ethnic homogeneity appears to be positively correlated with aggregate efficiency.

With regards to the institutional and corruption variables, the general picture that emerges from tables $4 \mathrm{a}$ to $4 \mathrm{e}$ is strikingly consistent across specifications, and regardless of the governance variable taken into account. Thus, in benchmark estimations, that is oddnumbered ones, the relevant governance indicator is always negatively signed or insignificant, the only exception being voice and accountability in the estimation that also features the CPI among regressors. Accordingly, aggregate efficiency unsurprisingly rises with the quality of governance as measured by the World Bank indicators.

In the same benchmark estimations, corruption indices lead to the same qualitative results. Namely, the coefficient that affects corruption is positive in six estimations out of fifteen, insignificant in seven estimations, and negative in only two estimations. If anything, this finding means that greater corruption is on average associated with greater inefficiency in the sample of our study. Again these results are in line with previous results on the impact of corruption on growth, like Mauro (1995), or productivity growth, like Olson et al. (2000).

However, the most striking result, which is central to the question that is raised in the present paper, materializes in even-numbered estimations, i.e. when the interaction term between corruption and other facets of governance is added to the set of explanatory variables. The coefficients that were significant in odd-numbered estimations remain significant after including the interaction term. The only exception is the voice and accountability index in estimation 4a.4, whose sign already appeared odd in 4a.3. In some of our estimations, coefficients that were not significant become significant. This is particularly the case of governance indices that are almost always significantly negative in these estimations, while they were often insignificant in previous estimations. Moreover, loglikelihood most of the time substantially increases with the inclusion of the interaction term, and even-numbered estimations pass the log-likelihood ratio test against odd-numbered ones. 
The last two findings are arguments against the pooling of countries regardless of the quality of their institutional framework.

But the truly remarkable feature of even-numbered estimations appears when one looks at the coefficients of corruption and of the interaction term. We observe that in these estimations corruption exhibits either a negative or insignificant coefficient. In addition, the interaction term is also either positive or insignificant. In terms of our specification, these results mean that in general $\delta_{1}$ is negative while $\delta_{2}$ is positive. In other words, we find evidence of the grease the wheels hypothesis.

Finding that $\delta_{1}$ is negative and $\delta_{2}$ positive may be consistent with both the strong and the weak form of the grease the wheels hypothesis. As indicated by expression (3b) discriminating between the two versions of the grease the wheels hypothesis requires to determine whether parameters $\delta_{1}$ and $\delta_{2}$ are such that the overall impact of corruption on inefficiency may be negative for some low values of the relevant governance index. In order to determine whether the displayed estimations are consistent with the strong version of the grease the wheels hypothesis, one must study each estimation in turn and examine jointly the estimated $\delta_{1}$ and $\delta_{2}$, and the range of the relevant governance index in the sample.

With these remarks in mind, one may classify our featured estimations in three categories. The first category consists of the estimations that show no sign of any relationship between corruption and efficiency. These are the estimations where neither $\delta_{1}$ nor $\delta_{2}$ is significant. Estimations 4a.4. and 4c.4 come into this category.

The other two categories are those consistent with either form of the grease the wheels hypothesis. ${ }^{13}$ These require closer scrutiny. The weak form of the hypothesis appears in estimations $4 \mathrm{a} .6,4 \mathrm{~b} .4$, and $4 \mathrm{~d} .2$, where $\delta_{2}$ is significantly positive but $\delta_{1}$ is not significantly different from zero. As governance indices are always positive, these estimations imply that corruption is positively associated with inefficiency in all countries, but more so in countries where governance is satisfactory. This is precisely what the weak form of the grease the wheels hypothesis predicts.

The last category comprises all the estimations that show evidence of the strong form of the grease the wheels hypothesis. The $\delta_{1}$ and $\delta_{2}$ coefficients of those estimations are such that the overall coefficient of corruption can be negative, at least for the country that exhibits the lowest value of the governance index. To illustrate this phenomenon, let us for instance

\footnotetext{
${ }^{13}$ There is no estimation where corruption remains positively and significantly correlated with inefficiency after the introduction of the interaction term. In other words, we find no instance of the sand the wheels hypothesis.
} 
focus on estimation $4 \mathrm{c} .2$, which estimates the interaction between corruption, as measured by the World Bank index, and government effectiveness. According to this estimation, $\delta_{1} \cong-0.4692$ and $\delta_{2} \cong 0.0765$. In addition, the country that fares worst in terms of government effectiveness (i.e. Zimbabwe) scores 2.74 on the government effectiveness index. Consequently, the total coefficient of corruption for this country is equal to $(-0.4692+0.0765 \times 2.74) \cong-0.2596$. According to estimation $4 \mathrm{c} .2$, this country may improve its efficiency by allowing corruption to rise. Moreover, all countries whose government effectiveness index is lower than $-\delta_{1} / \delta_{2} \cong 0.4692 / 0.0765 \cong 6.13$ may face the same possibility. This means that 29 countries in the sample may be in a position to benefit from a rise in corruption. Similar findings are obtained in estimations 4a.2, 4b.2, 4b.6, 4c.2, 4c.6, 4d.4, 4d.6, 4e.2, 4e.4, and 4e.6.

Table 5: summary of estimations

\begin{tabular}{|c|c|c|c|}
\hline & WB & CPI & WEI \\
\hline Voice & $\begin{array}{c}\text { Strong GWH } \\
\text { Threshold } \cong 3.70 \\
6 \text { countries }\end{array}$ & & Weak GWH \\
\hline Lackviol & $\begin{array}{c}\text { Strong GWH } \\
\text { Threshold } \cong 3.44 \\
6 \text { countries }\end{array}$ & Weak GWH & $\begin{array}{c}\text { Strong GWH } \\
\text { Threshold } \cong 5.18 \\
25 \text { countries }\end{array}$ \\
\hline Goveff & $\begin{array}{c}\text { Strong GWH } \\
\text { Threshold } \cong 6.13 \\
29 \text { countries }\end{array}$ & & $\begin{array}{c}\text { Strong GWH } \\
\text { Threshold } \cong 5.39 \\
26 \text { countries }\end{array}$ \\
\hline Reg & Weak GWH & $\begin{array}{c}\text { Strong GWH } \\
\text { Threshold } \cong 5.47 \\
6 \text { countries }\end{array}$ & $\begin{array}{c}\text { Strong GWH } \\
\text { Threshold } \cong 5.74 \\
28 \text { countries }\end{array}$ \\
\hline Rulelaw & $\begin{array}{c}\text { Strong GWH } \\
\text { Threshold } \cong 5.48 \\
25 \text { countries }\end{array}$ & $\begin{array}{c}\text { Strong GWH } \\
\text { Threshold } \cong 4.91 \\
1 \text { country }\end{array}$ & $\begin{array}{c}\text { Strong GWH } \\
\text { Threshold } \cong 5.47 \\
26 \text { countries }\end{array}$ \\
\hline
\end{tabular}

In a nutshell, out of the fifteen estimations that include an interaction term, ten show evidence of the strong form of the grease the wheels hypothesis, three are consistent with the weak form of the grease the wheels hypothesis, and two show no sign of a relationship between corruption and efficiency. None of them suggests a systematic detrimental effect of corruption on aggregate efficiency. Furthermore, it must be pointed out that at least one estimation consistent with the strong form of the grease the wheels hypothesis can be found for each dimension of governance. All in all, one can conclude that there is clear evidence of some form of grease the wheels hypothesis. 
An interesting by-product of our estimations is that they allow us to gauge the relative importance of the interrelationship between corruption and each of the five dimensions of governance being analyzed. ${ }^{14}$ It appears then that government efficiency is clearly the most robust governance index in our sample. It is thus significantly associated with inefficiency in all three baseline estimations and all three estimations that include an interaction with corruption. This is reassuring insofar as this is the aspect of governance that corruption is theoretically meant to grease. On the other hand, voice and accountability performs worst of the various dimensions of governance. Namely, it only appears significantly in one baseline estimation and two that include an interaction term. This finding is by and large consistent with the literature, where the correlation between democracy and economic outcomes usually appears fragile.

Finally, all other indices only appear significant in one baseline estimation out of three, as well as in all estimations including an interaction term.

Our findings therefore contrast with previous empirical results that have in general supported a clear negative impact of corruption on economic performance, such as Mauro (1995), or Mo (2001). Most often they have not taken into account the non-linearity of the estimated relationship. Thus it must be emphasized again that we could achieve more usual results in our benchmark estimations where the interaction of corruption with other dimensions of governance was not controlled for. The fact that our results are clearly at odds with those of Méon and Sekkat (2005), where those interactions were specifically taken into account may seem somewhat more puzzling. It must however be said that our estimations cannot be directly compared with those of the above-mentioned authors. Méon and Sekkat (2005) focused on the impact of corruption on growth and investment, while in this paper we analyze aggregate efficiency. Also, their period of study is 1970-1998, whereas we have focused on the years 1994-1997.

\subsection{A quantitative assessment}

To get a feel of the quantitative significance of our results, let us focus on three countries from our sample whose government efficiency indicators differ, say the Philippines, Tunisia, and Chile, and see what a reduction of corruption would imply for them. Our first

\footnotetext{
${ }^{14}$ The results also underline differences between corruption indices. The results obtained with the World Bank's index and Wei's index look very similar, while the CPI index stands out as slightly less robustly associated with efficiency than the other two. Although we have no ready explanation for these differences, the size of the sample may well play a sizeable role here.
} 
country is plagued by a deficient government. The government efficiency index of our second country is close to the threshold estimated in table 5. And finally, our third country boasts a government efficiency index well above the estimated threshold. To save on space, we focus on government efficiency, as it is the most relevant dimension of governance for the grease the wheels hypothesis. A similar exercise could be done with other indices. Let us now assume that these countries succeed in bringing down corruption by one standard deviation of the World Bank's corruption index, i.e. two points. Such a reduction would approximately bring down the level of corruption to that of Italy for the Philippines, to that of Chile for Tunisia, and to that of the Netherlands for Chile. ${ }^{15}$

The coefficients estimated in estimation $4 \mathrm{c} .2$ allow us to evaluate the impact of such a reduction of corruption on the aggregate efficiency of these three countries under study. ${ }^{16}$ To do so, the first step is to compute the overall coefficient of corruption for each country. With $\delta_{1} \cong-0.4692$ and $\delta_{2} \cong 0.075$, the overall coefficient of corruption reaches -0.0668 in the Philippines, -0.0097 in Tunisia, and +0.092 in Chile, given their governance indices. ${ }^{17}$ The same reduction in the World Bank corruption index would therefore result in a different impact on efficiency, and hence income. Thus, given each country's initial efficiency score and the quality of its government efficiency, the Philippines would witness a drop of 49.3 percentage points of its efficiency score, while Chile would see its efficiency score rise by 50.69 percentage points. The reduction of corruption will be accompanied by a small 5.76 percentage points reduction of Tunisia's efficiency score.

Moreover, these variations in efficiency are synonymous to variations in output per worker since they reflect each country's distance to the common production frontier. ${ }^{18}$ Thus, the Philippines' output per worker would fall from 1567 to 795 dollars per year, which is similar to that of Kenya. On the other hand, Chile's output per worker would rise from 7029 to 10590 dollars per year, which would bring it close to Portugal. Finally, Tunisia's output per worker would only rise marginally, from 4081 to 4316 dollars per year. This is not surprising,

\footnotetext{
${ }^{15}$ The rescaled value of the World Bank corruption index is equal to 5.46 for the Philippines, 4.96 for Tunisia, and 2.94 for Chile. Following a two points reduction in their indices, those countries would respectively end up near Italy, whose index is 3.4 , Chile, whose index is 2.94 , and the Netherlands, whose index is equal to 0.94 .

${ }^{16}$ In fact, the estimated coefficients do not directly measure the first derivative of efficiency with respect to corruption. Instead, they measure the derivative of $u_{i}$, defined as $u_{i}=-\log ($ efficiency). The variation of efficiency can therefore be estimated as $\Delta$ efficiency $=\left(\right.$ eefficiency $\left./ \partial u_{i}\right) \cdot \Delta u_{i}$.

${ }^{17}$ Recall that the coefficient of corruption in a country is a function of that country's government efficiency. The government efficiency index of the three countries under study is respectively equal to 5.26 for the Philippines, 6.26 for Tunisia, and 7.34 for Chile.

${ }^{18}$ The simulated value of output can easily be simply computed as $y_{i 1}=\frac{\text { efficiency } y_{i 0}}{\text { efficiency } y_{i 1}} y_{i 0}$.
} 
since government effectiveness in Tunisia is very close to the threshold value. The coefficient of corruption in that country is therefore very close to zero. At any rate, the main message of these simulations is that the impact of a reduction of corruption on output may be dramatic in countries where the governance index takes on extreme values. ${ }^{19}$ However, that impact varies wildly with the quality of the rest of the institutional framework, and can be either positive or negative.

\subsection{Robustness checks}

Although our results are obtained while controlling for several country-specific traits, one may wonder whether they are not subject to a multi-colinearity problem. Namely, one may for instance expect a positive correlation between corruption and other governance indicators on the one hand, and the three control variables on the other hand. It can thus be argued that greater openness to trade may reduce corruption or improve the institutional framework, as it encourages ideas to circulate and subjects domestic practices to foreign scrutiny. One may also suspect ethnic fractionalization to affect both institutions and economic performance, through its impact on trust and social cohesion. Finally, geography and latitude may also affect both economic performance, as suggested by Sachs (2001), and income, because, historically, it determined the strategy of colonizers, as Acemoglu et al. (2001) argue.

To check the robustness of our results to the choice of control variables, we therefore ran our estimations again, dropping one control variable at a time then dropping all of them. ${ }^{20}$ As table A1 in the appendix shows, our results were only slightly affected, either qualitatively or quantitatively.

Another source of skepticism was that our estimations did not discriminate between developed and developing countries. Pooling countries regardless of their level of development may nevertheless neglect the fact that they may be operating along different production frontiers. In addition, the determinants of efficiency may differ across developed

\footnotetext{
${ }^{19}$ Those orders of magnitude may even seem huge. One should recall that cross-country output level differences pertain to the long term, as Hall and Jones (1999) remark. The present orders of magnitude are moreover in line with those reported in the literature. For instance, Mauro (1995) finds that a one standard deviation reduction in corruption can raise an economy's growth rate by 0.8 points. After a couple of decades, this would result in a difference in its level of GDP comparable to the one that we describe here. Along similar lines, Hall and Jones (1999) observe that differences in institutional quality can account for a 25.2 to 38.4 -fold difference in output per worker across countries.

${ }^{20}$ To save on space, we restrict ourselves to one index of corruption, the World Bank index, and to one index of institutional quality, namely government effectiveness, which is the most relevant to test the grease the wheels hypothesis.
} 
and developing countries. To address this issue, we split our sample into two equivalent subsets according to per capita income, and created a dummy variable equal to one for every observation whose per capita income is greater than the median, and zero elsewhere. We then used this dummy variable in two ways. First, we interacted it with production factors' stocks, and included the resulting interaction terms as well as the dummy variable itself into the expression of the production frontier. This is equivalent to estimating a distinct production frontier for each sub-sample. The results displayed in table A2 of the appendix show that the coefficients of the corruption and governance indices were only slightly affected. Second, we added the dummy variable to the set of explanatory variables. The result of this estimation, also reported in table A2, also exhibits little influence on governance indicators. Our findings are therefore robust to distinguishing developed and developing countries.

We were also concerned that our results may be contingent on the period of study. We accordingly estimated the production frontier with data pertaining to the 1988-1990 period. That earlier period of time allowed for an additional robustness check, which consisted in using a different dataset on output and capital per worker, namely Easterly and Levine (2001)'s dataset. Table A2 reports the results of these estimations. Once again, the coefficients of the governance and corruption indices remained significant, and exhibited signs consistent with the grease the wheels hypothesis.

Our final concern was that the results might be driven by the Cobb-Douglas specification of the production frontier with constant returns to scale. We therefore tested two alternative specifications. The first one is a translog production function, which is specified as follows:

$$
\begin{aligned}
\ln (Y / L)_{i t} & =\alpha_{0}+\alpha_{1} \ln (K / L)_{i t}+\alpha_{2} \ln (H / L)_{i t}+\alpha_{3}\left[\ln (K / L)_{i t}\right]^{2}+\alpha_{4}\left[\ln (H / L)_{i t}\right]^{2} \\
& +\alpha_{5} \ln (K / L)_{i t} \ln (H / L)_{i t}+v_{i t}-u_{i t}
\end{aligned}
$$

The second one is a production frontier with variable returns to scale. Namely, the production frontier is similar to the one presented in equation (1) if we except that production, physical capital and human capital are not normalized by labor, and that labor is added as a term in the frontier. The results of these estimations are displayed in table A3. In both estimations, the coefficients of the corruption and governance indices remained similar to previous ones, both qualitatively and quantitatively. Our results are therefore robust to various specifications of the production frontier.

Our findings have thus survived several robustness checks, leading to coefficients of the corruption and governance indices that are consistent with the grease the wheels 
hypothesis. More to the point, it must be stressed that their magnitude was systematically consistent with the strong form of the grease the wheels hypothesis, implying that corruption may lead to greater efficiency in some countries of the sample.

\section{Concluding remarks}

The present paper specifically tests the grease the wheels hypothesis and the sand the wheels hypothesis of corruption by focusing on aggregate efficiency. Unlike most previous studies, the results provide no evidence of the sand the wheels hypothesis but substantial evidence of the grease the wheels hypothesis. Both the weak and the strong forms of the grease the wheels hypothesis are observed. Namely, although it is repeatedly found that corruption is less detrimental in countries where the rest of the institutional framework is weaker, our estimations do not always imply that an increase in corruption may be beneficial in at least one country in the sample. However, for each of the five dimensions of governance taken into account, we find evidence of the strong grease the wheels hypothesis in at least one estimation.

A possible policy implication of these results might be that countries plagued with a very inefficient institutional framework may benefit from letting corruption grow. This interpretation is however extreme and risky. A country that would let corruption frolic may find itself stuck later on with an even worse global institutional framework, and thus end up in a bad governance/low efficiency trap.

Encouraging countries to fight corruption while also striving to improve other aspects of governance, mainly government efficiency, constitutes perhaps a safer advice. Indeed, successful policy package should be multifaceted, while narrower reform programs may instead prove counter productive. Which of these two sets of advice to follow depends however on the dynamics of the interrelationship between corruption, governance, and economic performance, which is not fully understood yet. Understanding these dynamics should therefore feature highly on the political economy research agenda. 


\section{Appendix}

\section{A1: Countries in the sample}

Australia, Austria, Belgium, Bolivia, Cameroon, Canada, Chile, Colombia; Costa Rica, Denmark, Ecuador, Egypt, El Salvador, Finland, France, Ghana, Guatemala, Honduras, India, Indonesia, Ireland, Israel, Italy, Jamaica, Japan, Jordan, Kenya, Korea (Republic), Malawi, Malaysia, Mauritius, Mexico, Netherlands, New Zealand, Norway, Pakistan, Paraguay, Philippines, Portugal, Senegal, Singapore, South Africa, Sweden, Switzerland, Thailand, Tunisia, Turkey, Uganda, United Kingdom, USA, Uruguay, Venezuela, Zambia, Zimbabwe.

All countries are part of the sample for the World Bank measure of corruption. Countries in italics are not part of the sample for the CPI measure of corruption. Countries in bold are not part of the sample for the WEI measure of corruption. 


\section{A2: Robustness checks}

Table A1: sensitivity to changes in the set of control variables

\begin{tabular}{|c|c|c|c|c|}
\hline & $\begin{array}{l}\text { Without } \\
\text { Latitude }\end{array}$ & $\begin{array}{l}\text { Without } \\
\text { Ethnic }\end{array}$ & $\begin{array}{l}\text { Without } \\
\text { Openness }\end{array}$ & $\begin{array}{c}\text { Without } \\
\text { control } \\
\text { variables }\end{array}$ \\
\hline & A1.1 & A1.2 & A1.3 & A1.4 \\
\hline Intercept & $\begin{array}{c}0.4782 \\
(1.44)\end{array}$ & $\begin{array}{l}0.4270 \\
(1.12)\end{array}$ & $\begin{array}{c}0.4435 \\
(1.28)\end{array}$ & $\begin{array}{c}0.4395 \\
(1.38)\end{array}$ \\
\hline $\log (K / L)$ & $\begin{array}{c}0.7979 * * * \\
(37.17)\end{array}$ & $\begin{array}{c}0.7957 * * * \\
(28.24)\end{array}$ & $\begin{array}{c}0.7978 * * * \\
(36.58)\end{array}$ & $\begin{array}{c}0.8068 * * * \\
(39.91)\end{array}$ \\
\hline $\log (H / L)$ & $\begin{array}{c}0.1614 * * * \\
(2.82)\end{array}$ & $\begin{array}{c}0.1472 * * \\
(2.35)\end{array}$ & $\begin{array}{c}0.1527^{* *} \\
\quad(2.51)\end{array}$ & $\begin{array}{c}0.1604 * * * \\
(2.88)\end{array}$ \\
\hline Year94 & $\begin{array}{c}-0.0151 \\
(-0.44)\end{array}$ & $\begin{array}{c}-0.0141 \\
(-0.42)\end{array}$ & $\begin{array}{c}-0.0181 \\
(-0.55)\end{array}$ & $\begin{array}{c}-0.0174 \\
(-0.53)\end{array}$ \\
\hline Year95 & $\begin{array}{c}-0.0062 \\
(-0.18)\end{array}$ & $\begin{array}{c}-0.0065 \\
(-0.20)\end{array}$ & $\begin{array}{c}-0.0093 \\
(-0.28)\end{array}$ & $\begin{array}{c}-0.0072 \\
(-0.21)\end{array}$ \\
\hline Year96 & $\begin{array}{c}-0.0023 \\
(-0.07)\end{array}$ & $\begin{array}{c}-0.3445^{\mathrm{E}}-3 \\
(-0.01)\end{array}$ & $\begin{array}{c}-0.0025 \\
(-0.08)\end{array}$ & $\begin{array}{c}-0.0028 \\
(-0.08)\end{array}$ \\
\hline Intercept & $\begin{array}{c}3.9209 * * * \\
(4.56)\end{array}$ & $\begin{array}{c}3.9542 * * * \\
(4.16)\end{array}$ & $\begin{array}{c}4.0157 * * * \\
(5.43)\end{array}$ & $\begin{array}{c}4.2644 * * * \\
(5.37)\end{array}$ \\
\hline Corruption & $\begin{array}{c}-0.4750 * * * \\
(-3.43)\end{array}$ & $\begin{array}{c}-0.4579 * * * \\
(-2.95)\end{array}$ & $\begin{array}{c}-0.4757 * * * \\
(-3.94)\end{array}$ & $\begin{array}{c}-0.5085^{* * *} \\
(-3.80)\end{array}$ \\
\hline Corruption $\times$ Goveff & $\begin{array}{c}0.0786 * * * \\
(3.21)\end{array}$ & $\begin{array}{c}0.0757^{* *} \\
(2.50)\end{array}$ & $\begin{array}{c}0.0752 * * * \\
(3.29)\end{array}$ & $\begin{array}{c}0.0808 * * * \\
(2.99)\end{array}$ \\
\hline Goveff & $\begin{array}{c}-0.6596 * * * \\
(-4.63)\end{array}$ & $\begin{array}{c}-0.6341 * * * \\
(-3.27)\end{array}$ & $\begin{array}{c}-0.6596 * * * \\
(-5.47)\end{array}$ & $\begin{array}{c}-0.7125^{* * *} \\
(-5.08)\end{array}$ \\
\hline Openness & $\begin{array}{c}-0.0370 \\
(-0.33)\end{array}$ & $\begin{array}{c}-0.0805 \\
(-1.01)\end{array}$ & & \\
\hline Latitude & & $\begin{array}{c}-0.0032 \\
(-1.08)\end{array}$ & $\begin{array}{c}-0.0019 \\
(-0.55)\end{array}$ & \\
\hline Ethno. Frac. & $\begin{array}{c}0.0010 \\
(0.67) \\
\end{array}$ & & $\begin{array}{l}0.0012 \\
(1.02)\end{array}$ & \\
\hline Sigma & $\begin{array}{c}0.0647 * * * \\
(5.89)\end{array}$ & $\begin{array}{c}0.0632 * * * \\
(5.07)\end{array}$ & $\begin{array}{c}0.0646 * * * \\
(5.06)\end{array}$ & $\begin{array}{c}0.0725 * * * \\
(5.78)\end{array}$ \\
\hline Loglikelihood & 75.184 & 75.245 & 75.245 & 74.217 \\
\hline $\mathrm{N}$ & 216 & 216 & 216 & 216 \\
\hline
\end{tabular}

$t$-statistics are displayed in parentheses under the coefficient estimates. ${ }^{*}, * *, * * *$ denote an estimate significantly different from zero at the $10 \%, 5 \%$ or $1 \%$ level. 
Table A2: specificity of developing countries and sensitivity to the estimation period

\begin{tabular}{|c|c|c|c|}
\hline & $\begin{array}{c}\text { Development } \\
\text { dummy in the } \\
\text { frontier }\end{array}$ & \begin{tabular}{|c|}
$\begin{array}{c}\text { Development } \\
\text { dummy in the } \\
\text { inefficiency } \\
\text { equation }\end{array}$ \\
\end{tabular} & $1988-1990$ \\
\hline & A 2.1 & A 2.2 & A 2.3 \\
\hline Intercept & $\begin{array}{l}0.6695 \\
(1.23)\end{array}$ & $\begin{array}{c}0.4504 \\
(1.28)\end{array}$ & $\begin{array}{c}4.7368 * * * \\
(26.75)\end{array}$ \\
\hline $\log (\mathrm{K} / \mathrm{L})$ & $\begin{array}{c}0.6106 * * * \\
(10.26)\end{array}$ & $\begin{array}{c}0.7952 * * * \\
(34.61)\end{array}$ & $\begin{array}{c}0.4813 * * * \\
(20.12)\end{array}$ \\
\hline $\log (\mathrm{H} / \mathrm{L})$ & $\begin{array}{c}0.1359 \\
(1.45)\end{array}$ & $\begin{array}{c}0.1518^{* *} \\
(2.49)\end{array}$ & $\begin{array}{l}0.0610 \\
(1.12)\end{array}$ \\
\hline $\mathrm{D}$ & $\begin{array}{c}0.2417 \\
(0.36)\end{array}$ & & \\
\hline $\mathrm{D}^{*} \log (\mathrm{K} / \mathrm{L})$ & $\begin{array}{c}0.1998 * * * \\
(3.05)\end{array}$ & & \\
\hline $\mathrm{D}^{*} \log (\mathrm{H} / \mathrm{L})$ & $\begin{array}{l}0.1471 \\
(1.20)\end{array}$ & & \\
\hline Year94 & $\begin{array}{r}-0.0083 \\
(-0.27)\end{array}$ & $\begin{array}{r}-0.0175 \\
(-0.52)\end{array}$ & \\
\hline Year95 & $\begin{array}{r}-0.0047 \\
(-0.16)\end{array}$ & $\begin{array}{r}-0.0073 \\
(-0.22)\end{array}$ & \\
\hline Year96 & $\begin{array}{c}0.0031 \\
(0.10)\end{array}$ & $\begin{array}{c}-0.0020 \\
(-0.06)\end{array}$ & \\
\hline Year88 & & & $\begin{array}{c}-0.0193 \\
(-0.62)\end{array}$ \\
\hline Year89 & & & $\begin{array}{c}-0.0058 \\
(-0.19) \\
\end{array}$ \\
\hline Intercept & $\begin{array}{c}3.5340 * * * \\
(4.68)\end{array}$ & $\begin{array}{c}3.9709^{* * * *} \\
(4.90)\end{array}$ & $\begin{array}{c}2.8147 * * * \\
(3.61)\end{array}$ \\
\hline Corruption & $\begin{array}{c}-0.3601 * * * \\
(-3.08)\end{array}$ & $\begin{array}{c}-0.4715^{* * *} \\
(-3.45)\end{array}$ & $0.2641 * *$ \\
\hline Corruption $\times$ Goveff & $\begin{array}{c}0.0452^{* *} \\
(2.16)\end{array}$ & $\begin{array}{c}0.0768^{* * * *} \\
(2.98)\end{array}$ & $\begin{array}{c}0.0523 * * * \\
(2.82)\end{array}$ \\
\hline Goveff & $\begin{array}{c}-0.5077 * * * \\
(-4.19)\end{array}$ & $\begin{array}{c}-0.6413^{* * *} \\
(-4.45)\end{array}$ & $\begin{array}{c}0.5299 * * * \\
(-4.37)\end{array}$ \\
\hline Openness & $\begin{array}{c}-0.1963^{*} \\
(-1.89)\end{array}$ & $\begin{array}{c}-0.0618 \\
(-0.50)\end{array}$ & $\begin{array}{c}0.0013^{*} \\
(1.90)\end{array}$ \\
\hline Latitude & $\begin{array}{c}-0.0073^{*} \\
(-1.77)\end{array}$ & $\begin{array}{c}-0.0025 \\
(-0.68)\end{array}$ & $\begin{array}{l}0.0017 \\
(-1.13)\end{array}$ \\
\hline $\begin{array}{l}\text { Ethno. Frac. } \\
\text { D }\end{array}$ & $\begin{array}{c}0.0040^{* *} \\
(2.20)\end{array}$ & $\begin{array}{c}0.7493 \mathrm{E}-3 \\
(0.44) \\
-0.0074 \\
(-0.06) \\
\end{array}$ & $\begin{array}{c}0.0036^{* * *} \\
(3.19)\end{array}$ \\
\hline Sigma & $\begin{array}{c}0.0486^{* * * *} \\
(5.42)\end{array}$ & $\begin{array}{c}0.0623^{* * * *} \\
(5.18)\end{array}$ & $\begin{array}{c}0.0553 * * * \\
(6.32)\end{array}$ \\
\hline Loglikelihood & 90.255 & 75.538 & 66.922 \\
\hline $\mathrm{N}$ & 216 & 216 & 186 \\
\hline
\end{tabular}


Table A3: sensitivity to the specification of the production function

\begin{tabular}{|c|c|c|}
\hline & $\begin{array}{l}\text { Translog } \\
\text { form }\end{array}$ & $\begin{array}{c}\text { Variable returns to } \\
\text { scale }\end{array}$ \\
\hline & A3.1 & A3.2 \\
\hline Intercept & $\begin{array}{c}-5.4090 * * * \\
(-3.03)\end{array}$ & $\begin{array}{l}1.0194 \\
(1.25)\end{array}$ \\
\hline $\log (\mathrm{K} / \mathrm{L})$ & $\begin{array}{l}2.0178 * * * \\
(7.53)\end{array}$ & \\
\hline $\log (\mathrm{H} / \mathrm{L})$ & $\begin{array}{c}-1.6115^{* *} \\
(-2.43)\end{array}$ & \\
\hline$[\log (\mathrm{K} / \mathrm{L})]^{2}$ & $\begin{array}{c}-0.1228 * * \\
(-1.96)\end{array}$ & \\
\hline$[\log (\mathrm{H} / \mathrm{L})]^{2}$ & $\begin{array}{c}-0.0299 * * \\
(-2.28)\end{array}$ & \\
\hline $\log (\mathrm{K} / \mathrm{L}) \times \log (\mathrm{H} / \mathrm{L})$ & $\begin{array}{l}0.2268 * * * \\
(4.84)\end{array}$ & \\
\hline $\log (\mathrm{L})$ & & $\begin{array}{c}0.0915^{*} \\
(1.91)\end{array}$ \\
\hline $\log (K)$ & & $\begin{array}{l}0.7829 * * * \\
(37.55)\end{array}$ \\
\hline $\log (H)$ & & $\begin{array}{l}0.1473 * * \\
\quad(2.45)\end{array}$ \\
\hline Year94 & $\begin{array}{c}-0.0143 \\
(-0.42)\end{array}$ & $\begin{array}{c}-0.0209 \\
(-0.62)\end{array}$ \\
\hline Year95 & $\begin{array}{r}-0.0069 \\
(-0.20)\end{array}$ & $\begin{array}{r}-0.0125 \\
(-0.38)\end{array}$ \\
\hline Year96 & $\begin{array}{c}-0.0036 \\
(-0.11)\end{array}$ & $\begin{array}{c}-0.0059 \\
(-0.18)\end{array}$ \\
\hline Intercept & $\begin{array}{l}3.6693 * * * \\
(4.31)\end{array}$ & $\begin{array}{l}3.7293 * * * \\
\quad(5.44)\end{array}$ \\
\hline Corruption & $\begin{array}{c}-0.3873 * * * \\
(-3.00)\end{array}$ & $\begin{array}{c}-0.4417 * * * \\
\quad(-4.05)\end{array}$ \\
\hline Corruption $\times$ Goveff & $\begin{array}{c}0.0493 * * \\
(2.17)\end{array}$ & $\begin{array}{l}0.0747 * * * \\
\quad(3.68)\end{array}$ \\
\hline Goveff & $\begin{array}{c}-0.5302^{* * *} \\
(-3.75)\end{array}$ & $\begin{array}{c}-0.6049 * * * \\
(-5.11)\end{array}$ \\
\hline Openness & $\begin{array}{c}-0.0933 \\
(-0.95)\end{array}$ & $\begin{array}{c}-0.0701 \\
(-0.68)\end{array}$ \\
\hline Latitude & $\begin{array}{c}-0.0062 * \\
(-1.75)\end{array}$ & $\begin{array}{r}-0.0017 \\
(-0.52)\end{array}$ \\
\hline Ethno. Frac. & $\begin{array}{l}0.0020 \\
(1.37)\end{array}$ & $\begin{array}{l}0.0013 \\
(0.90)\end{array}$ \\
\hline Sigma & $\begin{array}{c}0.0478 * * * \\
(5.11)\end{array}$ & $\begin{array}{c}0.0546 * * * \\
(4.99)\end{array}$ \\
\hline Loglikelihood & 88.693 & 78.304 \\
\hline $\mathrm{N}$ & 216 & 216 \\
\hline
\end{tabular}

$t$-statistics are displayed in parentheses under the coefficient estimates. ${ }^{*}, * *, * * *$ denote an estimate significantly different from zero at the $10 \%, 5 \%$ or $1 \%$ level. 


\section{References}

Acemoglu, D., S. Johnson, and J.A. Robinson (2001) "The Colonial Origins of Comparative Development: An Empirical Investigation”, American Economic Review, vol. 91 n5, p.1369-1401.

Ades A. and R. Di Tella (1997) "The New Economics of Corruption: A Survey and Some Results", Political Studies, vol. 45 (special issue), p.496-515.

Adkins, C., Moomaw, R. and A. Savvides (2002) "Institutions, Freedom, and Technical Efficiency”, Southern Economic Journal, vol. 69 n¹, p.92-108.

Aidt T.S. (2003) "Economic Analysis of Corruption: A Survey”, Economic Journal, vol. 113 $\mathrm{n}^{\circ} 491, \mathrm{p} .632-652$.

Aigner D., C.A.K. Lovell and P. Schmidt (1977) "Formulation and Estimation of Stochastic Frontier Production Models", Journal of Econometrics, vol. 6 n¹, p.21-37.

Bailey D.H. (1966) "The Effects of Corruption in a Developing Nation”, Western Political Quarterly, vol. 19 n4, p.719-732. Reprint in Political Corruption: A Handbook, A.J. Heidenheimer, M. Johnston and V.T. LeVine (eds.), Oxford, Transaction Books, p.934-952, 1989.

Bardhan P. (1997) “Corruption and Development: A Review of Issues”, Journal of Economic Literature, vol. $35 \mathrm{n}^{\circ} 3$, p.1320-1346.

Barro R.J. and J.W. Lee (2000) "International Data on Educational Attainment Updates and Implications", NBER Working Papers: 7911.

Battese G.E. and T.J. Coelli (1995) “A Model for Technical Inefficiency Effects in a Stochastic Production Frontier for Panel Data", Empirical Economics, vol. 20 n², p.325-332.

Beck P.J. and M.W. Maher (1986) “A Comparison of Bribery and Bidding in Thin Markets”, Economics Letters, vol. 20, p.1-5.

Caselli F. (2005), “Accounting for Cross-country Income Differences”, in P. Aghion and S. Durlauf (eds.) Handbook of Economic Growth, Elsevier, p.679-742.

Coelli T.J. (1996) “A Guide to Frontier 4.1: A Computer Program for Stochastic Production and Cost Function Estimation", Centre for Efficiency and Productivity Analysis, University of New England, Working Paper 96/07.

Dreher A. and F. Schneider (2006a) "Corruption and the shadow economy - substitutes or complements?", in: M. Kreutner (ed.), The Corruption Monster - Ethik, Politik und Korruption, Czernin Verlag, p. 363-370. 
Dreher A. and F. Schneider (2006b) "Corruption and the Shadow Economy: An Empirical Analysis", KOF Working Paper 123, ETH Zurich.

Dreher A., C. Kotsogiannis, and S. McCorriston (2007) "Corruption Around the World: Evidence from a Structural Model", Journal of Comparative Economics, 443-466.

Easterly W. and R. Levine (2001) “It's Not Factor Accumulation: Stylized Facts and Growth Models”, World Bank Economic Review, vol. 15 n², p.177-219.

Easterly W. and R. Levine (2003) "Tropics, Germs, and Crops: How Endowments Influence Economic Development”, Journal of Monetary Economics, vol. 50 n²1, p.3-39.

Edwards S. (1998) "Openness, Productivity and Growth: What Do We Really Know?" Economic Journal, vol. 108, p.383-398.

Ehrlich I. and F. Lui (1999) "Bureaucratic Corruption and Endogenous Economic Growth", Journal of Political Economy, vol. 107 nº 6 , p.S270-S293.

Friedman E., S. Johnson, D. Kaufmann, and P. Zoido-Lobaton (2000) "Dodging the Grabbing Hand: The Determinants of Unofficial Activity in 69 Countries", Journal of Public Economics, vol. 76 n³, p. 459-493.

Hall R. and C.I. Jones (1999) "Why Do Some Countries produce So Much More Output Per Worker Than Others?”, Quarterly Journal of Economics, vol. 114 n¹, p.83-116.

Henisz W.J. (2000) “The Institutional Environment for Economic Growth”, Economics and Politics, vol. $12 \mathrm{n}^{\circ} 1, \mathrm{p} .1-31$.

Huntington S.P. (1968) Political Order in Changing Societies. New Haven, Yale University Press.

Kaufmann D. and S.-J. Wei (1999) “Does 'Grease Money' Speed up the Wheels of Commerce?”, NBER Working Paper, n7093.

Kaufmann D., Kraay, A. and P. Zoido-Lobaton (1999a) "Aggregating Governance Indicators”, World Bank, Working Paper n²195.

Kaufmann D., Kraay, A. and P. Zoido-Lobaton (1999b) “Governance Matters”, World Bank, Working Paper $n^{\circ} 2196$.

Kneller R. and P.A. Stevens (2003) "The specification of the aggregate production function in the presence of inefficiency”, Economics Letters, vol. 81 n², p.223-226.

Kurer O. (1993) "Clientelism, Corruption and the Allocation of Resources", Public Choice, vol. $77 \mathrm{n}^{\circ} 2$, p. $259-273$.

Lambsdorff J.G. (2003) “How Corruption Affects Productivity”, Kyklos, vol. 56, n4, p.457474. 
Leff N.H. (1964) "Economic Development through Bureaucratic Corruption", American Behavioral Scientist, vol. 8, n³, p.8-14. Reprint in Political corruption: A handbook, A.J. Heidenheimer, M. Johnston and V.T. LeVine (eds.), Oxford, Transaction Books, p.389-403, 1989.

Leys C. (1965) “What Is the Problem about Corruption?”, Journal of Modern African Studies, vol. 3, $\mathrm{n}^{\circ} 2$, p.215-230. Reprint in Political corruption: A handbook, A.J. Heidenheimer, M. Johnston and V.T. LeVine (eds.), Oxford, Transaction Books, p.5166, 1989.

Lien D.H.D. (1986) “A Note on Competitive Bribery Games”, Economics Letters, vol. 22, p.337-341.

Lui F.T. (1985) “An Equilibrium Queuing Model of Bribery”, Journal of Political Economy, vol. $93, \mathrm{n}^{\circ} 4$, p.760-781.

Mauro P. (1995) “Corruption and Growth”, Quarterly Journal of Economics, vol. 110 n³, p.681-712.

Mauro P. (1998) "Corruption and the Composition of Government Expenditure", Journal of Public Economics, vol. 69 n², p.263-279.

Méon P.-G. and K. Sekkat (2005) “Does Corruption Grease or Sand the Wheels of Growth?”, Public Choice, vol. 122 n$^{\circ} 1-2$, p.69-97.

Mo P.H. (2001) "Corruption and Economic Growth", Journal of Comparative Economics, vol. $29 \mathrm{n}^{\circ} 1$, p.66-79.

Moroney J. and C.A.K. Lovell (1997) "The Relative Efficiencies of Market and Planned Economies", Southern Economic Journal vol. 63 n4, p.1084-1093.

Myrdal G. (1968) Asian Drama: An Enquiry into the Poverty of Nations, vol. 2, New York, the Twentieth Century Fund. Reprint in Political Corruption: A Handbook, A.J. Heidenheimer, M. Johnston and V.T. LeVine (eds.), Oxford, Transaction Books, p.953-961, 1989.

Nehru V. and Dhareshwar A., "New Estimates of Total Factor Productivity Growth for Developing and Industrial Countries”, Policy Research Working Paper n ${ }^{\circ} 1313$, World Bank, 1994.

Nye J.S. (1967) "Corruption and political development: a cost-benefit analysis", American Political Science Review, vol. 50, n², p.417-427. Reprint in Political corruption: A handbook, A.J. Heidenheimer, M. Johnston and V.T. LeVine (eds.), Oxford, Transaction Books, p.51-66, 1989. 
Olson M., Sarna, N., and A.V. Svamy (2000) “Governance and Growth: A Simple Hypothesis Explaining Cross-Country Differences in Productivity Growth". Public Choice vol. 102 n³-4, p.341-364.

Rock M.T., and H. Bonnett (2004) "The comparative politics of corruption: accounting for the East Asian paradox in empirical studies of corruption, growth and investment", World Development, vol. 32 n6, p.999-1017.

Rose-Ackerman R. (1997) "The Political Economy of Corruption", in Corruption and the global economy, K.A. Elliott (ed.), Washington DC, Institute for International Economics, p.31-60.

Sachs J. (2001) “Tropical Underdevelopment”. NBER Working paper n8119.

Sachs J. and Warner A. (1995) "Economic reform and the process of global integration" Brookings Papers of Economic Activity, n¹, p.1-18.

Shleifer A. and R.W. Vishny (1993) “Corruption”, Quarterly Journal of Economics, vol. 108 $\mathrm{n}^{\circ} 3, \mathrm{p} .599-617$.

Wei S.-J. (2000) "Local Corruption and Global Capital Flows", Brookings Papers on Economic Activity, vol. 2, p.303-346. 


\section{PAPIERS}

\section{Laboratoire de Recherche en Gestion \& Economie (LARGE)}

D.R. $\mathrm{n}^{\circ} 1$ "Bertrand Oligopoly with decreasing returns to scale", J. Thépot, décembre 1993

D.R. $\mathrm{n}^{\circ} 2$ "Sur quelques méthodes d'estimation directe de la structure par terme des taux d'intérêt", P. Roger - N. Rossiensky, janvier 1994

D.R. $n^{\circ} 3$ "Towards a Monopoly Theory in a Managerial Perspective", J. Thépot, mai 1993

D.R. n 4 "Bounded Rationality in Microeconomics", J. Thépot, mai 1993

D.R. n 5 "Apprentissage Théorique et Expérience Professionnelle", J. Thépot, décembre 1993

D.R. $n^{\circ} 6$ "Stratégic Consumers in a Duable-Goods Monopoly", J. Thépot, avril 1994

D.R. n 7 "Vendre ou louer ; un apport de la théorie des jeux", J. Thépot, avril 1994

D.R. $n^{\circ} 8$ "Default Risk Insurance and Incomplete Markets", Ph. Artzner - FF. Delbaen, juin 1994

D.R. $n^{\circ} 9$ "Les actions à réinvestissement optionnel du dividende", C. Marie-Jeanne - P. Roger, janvier 1995

D.R. $n^{\circ} 10$ "Forme optimale des contrats d'assurance en présence de coûts administratifs pour l'assureur", S. Spaeter, février 1995

D.R. n 11 "Une procédure de codage numérique des articles", J. Jeunet, février 1995

D.R. $n^{\circ} 12$ Stabilité d'un diagnostic concurrentiel fondé sur une approche markovienne du comportement de rachat du consommateur", N. Schall, octobre 1995

D.R. $n^{\circ} 13$ "A direct proof of the coase conjecture", J. Thépot, octobre 1995

D.R. n 14 "Invitation à la stratégie", J. Thépot, décembre 1995

D.R. n 15 "Charity and economic efficiency", J. Thépot, mai 1996 
D.R. $n^{\circ} 16$ "Princing anomalies in financial markets and non linear pricing rules", P. Roger, mars 1996

D.R. n 17 "Non linéarité des coûts de l'assureur, comportement de prudence de l'assuré et contrats optimaux", S. Spaeter, avril 1996

D.R. $n^{\circ} 18$ "La valeur ajoutée d'un partage de risque et l'optimum de Pareto : une note", L. Eeckhoudt - P. Roger, juin 1996

D.R. $\mathrm{n}^{\circ} 19$ "Evaluation of Lot-Sizing Techniques : A robustess and Cost Effectiveness Analysis", J. Jeunet, mars 1996

D.R. n 20 "Entry accommodation with idle capacity", J. Thépot, septembre 1996

D.R. n 21 "Différences culturelles et satisfaction des vendeurs : Une comparaison internationale", E. Vauquois-Mathevet - J.Cl. Usunier, novembre 1996

D.R. $\mathrm{n}^{\circ} 22$ "Evaluation des obligations convertibles et options d'échange", A. Schmitt - F. Home, décembre 1996

D.R n 23 "Réduction d'un programme d'optimisation globale des coûts et diminution du temps de calcul, J. Jeunet, décembre 1996

D.R. $n^{\circ} 24$ "Incertitude, vérifiabilité et observabilité : Une relecture de la théorie de l'agence", J. Thépot, janvier 1997

D.R. $\mathrm{n}^{\circ} 25$ "Financement par augmentation de capital avec asymétrie d'information : l'apport du paiement du dividende en actions", C. Marie-Jeanne, février 1997

D.R. $\mathrm{n}^{\circ} 26$ "Paiement du dividende en actions et théorie du signal", C. Marie-Jeanne, février 1997

D.R. n 27 "Risk aversion and the bid-ask spread", L. Eeckhoudt - P. Roger, avril 1997

D.R. $n^{\circ} 28$ "De l'utilité de la contrainte d'assurance dans les modèles à un risque et à deux risques", S. Spaeter, septembre 1997

D.R. $n^{\circ} 29$ "Robustness and cost-effectiveness of lot-sizing techniques under revised demand forecasts", J. Jeunet, juillet 1997

D.R. $n^{\circ} 30$ "Efficience du marché et comparaison de produits à l'aide des méthodes d'enveloppe (Data envelopment analysis)", S. Chabi, septembre 1997

D.R. n 31 "Qualités de la main-d'œuvre et subventions à l'emploi : Approche microéconomique", J. Calaza - P. Roger, février 1998

D.R n 32 "Probabilité de défaut et spread de taux : Etude empirique du marché français", M. Merli - P. Roger, février 1998

D.R. n 33 "Confiance et Performance : La thèse de Fukuyama", 


\section{J.Cl. Usunier - P. Roger, avril 1998}

D.R. $n^{\circ} 34$ "Measuring the performance of lot-sizing techniques in uncertain environments", J. Jeunet - N. Jonard, janvier 1998

D.R. n 35 "Mobilité et décison de consommation : premiers résultas dans un cadre monopolistique", Ph. Lapp, octobre 1998

D.R. $\mathrm{n}^{\circ} 36$ "Impact du paiement du dividende en actions sur le transfert de richesse et la dilution du bénéfice par action", C. Marie-Jeanne, octobre 1998

D.R. n ${ }^{\circ} 37$ "Maximum resale-price-maintenance as Nash condition", J. Thépot, novembre 1998

D.R. $\mathrm{n}^{\circ} 38$ "Properties of bid and ask prices in the rank dependent expected utility model", P. Roger, décembre 1998

D.R. n 39 "Sur la structure par termes des spreads de défaut des obligations », Maxime Merli / Patrick Roger, septembre 1998

D.R. $n^{\circ} 40 \quad$ "Le risque de défaut des obligations : un modèle de défaut temporaire de l'émetteur", Maxime Merli, octobre 1998

D.R. n ${ }^{\circ} 41$ "The Economics of Doping in Sports", Nicolas Eber / Jacques Thépot, février 1999

D.R. $\mathrm{n}^{\circ} 42$ "Solving large unconstrained multilevel lot-sizing problems using a hybrid genetic algorithm", Jully Jeunet, mars 1999

D.R n 43 "Niveau général des taux et spreads de rendement", Maxime Merli, mars 1999

D.R. $\mathrm{n}^{\circ} 44$ "Doping in Sport and Competition Design", Nicolas Eber / Jacques Thépot, septembre 1999

D.R. n 45 "Interactions dans les canaux de distribution", Jacques Thépot, novembre 1999

D.R. n 46 "What sort of balanced scorecard for hospital", Thierry Nobre, novembre 1999

D.R. n 47 "Le contrôle de gestion dans les PME", Thierry Nobre, mars 2000

D.R. n ${ }^{\circ} 48$ "Stock timing using genetic algorithms", Jerzy Korczak - Patrick Roger, avril 2000

D.R. n 49 "On the long run risk in stocks : A west-side story", Patrick Roger, mai 2000

D.R. $\mathrm{n}^{\circ} 50$ "Estimation des coûts de transaction sur un marché gouverné par les ordres : Le cas des composantes du CAC40", Laurent Deville, avril 2001

D.R. $n^{\circ} 51$ "Sur une mesure d'efficience relative dans la théorie du portefeuille de Markowitz", Patrick Roger / Maxime Merli, septembre 2001 
D.R. $n^{\circ} 52$ "Impact de l'introduction du tracker Master Share CAC 40 sur la relation de parité callput", Laurent Deville, mars 2002

D.R. n 53 "Market-making, inventories and martingale pricing", Patrick Roger / Christian At / Laurent Flochel, mai 2002

D.R. $n^{\circ} 54$ "Tarification au coût complet en concurrence imparfaite", Jean-Luc Netzer / Jacques Thépot, juillet 2002

D.R. $n^{\circ} 55$ "Is time-diversification efficient for a loss averse investor ?", Patrick Roger, janvier 2003

D.R. $\mathrm{n}^{\circ} 56$ “Dégradations de notations du leader et effets de contagion”, Maxime Merli / Alain Schatt, avril 2003

D.R. n 57 “Subjective evaluation, ambiguity and relational contracts”, Brigitte Godbillon, juillet 2003

D.R. $n^{\circ} 58$ "A View of the European Union as an Evolving Country Portfolio", Pierre-Guillaume Méon / Laurent Weill, juillet 2003

D.R. n 59 “Can Mergers in Europe Help Banks Hedge Against Macroeconomic Risk ?”, Pierre-Guillaume Méon / Laurent Weill, septembre 2003

D.R. $n^{\circ} 60$ "Monetary policy in the presence of asymmetric wage indexation", Giuseppe Diana / Pierre-Guillaume Méon, juillet 2003

D.R. $n^{\circ} 61$ “Concurrence bancaire et taille des conventions de services”, Corentine Le Roy, novembre 2003

D.R. n 62 “Le petit monde du CAC 40”, Sylvie Chabi / Jérôme Maati

D.R. $n^{\circ} 63$ "Are Athletes Different? An Experimental Study Based on the Ultimatum Game”, Nicolas Eber / Marc Willinger

D.R. n 64 "Le rôle de l'environnement réglementaire, légal et institutionnel dans la défaillance des banques : Le cas des pays émergents”, Christophe Godlewski, janvier 2004

D.R. $n^{\circ} 65$ "Etude de la cohérence des ratings de banques avec la probabilité de défaillance bancaire dans les pays émergents”, Christophe Godlewski, Mars 2004

D.R. n 66 "Le comportement des étudiants sur le marché du téléphone mobile : Inertie, captivité ou fidélité ?”, Corentine Le Roy, Mai 2004

D.R. $n^{\circ} 67$ "Insurance and Financial Hedging of Oil Pollution Risks”, André Schmitt / Sandrine Spaeter, September, 2004

D.R. $\mathrm{n}^{\circ} 68$ "On the Backwardness in Macroeconomic Performance of European Socialist Economies”, Laurent Weill, September, 2004

D.R. $n^{\circ} 69$ "Majority voting with stochastic preferences: The whims of a committee are smaller than the whims of its members”, Pierre-Guillaume Méon, September, 2004 
D.R. $\mathrm{n}^{\circ} 70$ "Modélisation de la prévision de défaillance de la banque : Une application aux banques des pays émergents”, Christophe J. Godlewski, octobre 2004

D.R. $\mathrm{n}^{\circ} 71$ "Can bankruptcy law discriminate between heterogeneous firms when information is incomplete ? The case of legal sanctions", Régis Blazy, october 2004

D.R. n 72 “La performance économique et financière des jeunes entreprises”, Régis Blazy/Bertrand Chopard, octobre 2004

D.R. $\mathrm{n}^{\circ} 73$ "Ex Post Efficiency of bankruptcy procedures : A general normative framework”, Régis Blazy / Bertrand Chopard, novembre 2004

D.R. n 74 “Full cost pricing and organizational structure”, Jacques Thépot, décembre 2004

D.R. $\mathrm{n}^{\circ} 75$ "Prices as strategic substitutes in the Hotelling duopoly”, Jacques Thépot, décembre 2004

D.R. n 76 "Réflexions sur l'extension récente de la statistique de prix et de production à la santé et à l'enseignement”, Damien Broussolle, mars 2005

D. R. n 77 "Gestion du risque de crédit dans la banque : Information hard, information soft et manipulation ”, Brigitte Godbillon-Camus / Christophe J. Godlewski

D.R. n 78 "Which Optimal Design For LLDAs”, Marie Pfiffelmann

D.R. $\mathrm{n}^{\circ} 79$ “Jensen and Meckling 30 years after : A game theoretic view”, Jacques Thépot

D.R. n 80 “Organisation artistique et dépendance à l'égard des ressources”, Odile Paulus, novembre 2006

D.R. $n^{\circ} 81$ "Does collateral help mitigate adverse selection? A cross-country analysis”, Laurent Weill -Christophe J. Godlewski, novembre 2006

D.R. $\mathrm{n}^{\circ} 82$ "Why do banks ask for collateral and which ones ?”, Régis Blazy - Laurent Weill, décembre 2006

D.R. $n^{\circ} 83$ "The peace of work agreement : The emergence and enforcement of a swiss labour market institution”, D. Broussolle, janvier 2006.

D.R. $\mathrm{n}^{\circ} 84$ "The new approach to international trade in services in view of services specificities : Economic and regulation issues”, D. Broussolle, septembre 2006.

D.R. $n^{\circ} 85$ "Does the consciousness of the disposition effect increase the equity premium" ?, P. Roger, juin 2007

D.R. n 86 "Les déterminants de la décision de syndication bancaire en France”, Ch. J. Godlewski

D.R. n 87 “Syndicated loans in emerging markets”, Ch. J. Godlewski / L. Weill, mars 2007

D.R. $n^{\circ} 88$ "Hawks and loves in segmented markets : A formal approach to competitive 
aggressiveness”, Claude d’Aspremont / R. Dos Santos Ferreira / J. Thépot, mai 2007

D.R. n 89 “On the optimality of the full cost pricing”, J. Thépot, février 2007

D.R. n'90 "SME's main bank choice and organizational structure : Evidence from France”, H. El Hajj Chehade / L. Vigneron, octobre 2007

D.R n 91 “How to solve St Petersburg Paradox in Rank-Dependent Models” ?, M. Pfiffelmann, octobre 2007

D.R. $\mathrm{n}^{\circ} 92$ "Full market opening in the postal services facing the social and territorial cohesion goal in France”, D. Broussolle, novembre 2007

D.R. $n^{\circ}$ 2008-01 A behavioural Approach to financial puzzles, M.H. Broihanne, M. Merli, P. Roger, janvier 2008

D.R. $\mathrm{n}^{\circ}$ 2008-02 What drives the arrangement timetable of bank loan syndication ?, Ch. J. Godlewski, février 2008

D.R. $n^{\circ}$ 2008-03 Financial intermediation and macroeconomic efficiency, Y. Kuhry, L. Weill, février 2008

D.R. $n^{\circ}$ 2008-04 The effects of concentration on competition and efficiency : Some evidence from the french audit market, G. Broye, L. Weill, février 2008

D.R. $\mathrm{n}^{\circ}$ 2008-05 Does financial intermediation matter for macroeconomic efficiency?, P.G. Méon, L. Weill, février 2008

D.R. $n^{\circ}$ 2008-06 Is corruption an efficient grease ?, P.G. Méon, L. Weill, février 2008

D.R. $\mathrm{n}^{\circ}$ 2008-07 Convergence in banking efficiency across european countries, L. Weill, Février 2008. 